\title{
PROCESY PUSTNUTÍ, VÁLEČNÉ ŠKODY A TZV. SOCIÁLNÍ ÚHORY. CHEBSKO V POZDNÍM STŘEDOVĚKU
}

\author{
TOMÁŠ KLÍR
}

\begin{abstract}
Abstrakt: Cílem studie je konkretizovat naše poznatky o procesu pustnutí venkovských sídlišt', průběhu a dopadu lokálních konfliktů a o tzv. sociálních úhorech v pozdním středověku. Chebsko bylo vybráno kvůli mimořádné pramenné evidenci v podobě rejstř́ků zemské berně (1392-1757). Ty dovoluji analyzovat sociálně-ekonomický, demografický a sídelní vývoj více než stovky vsí, a to na úrovni jednotlivých usedlostí doslova rok po roce. Analýza ukazuje, že: 1) primárním hybatelem procesu pustnutí koncem 14. století byla depopulace vyvolaná snad morovými vlnami; ostatni faktory mély sekundární význam, na druhé straně však ovlivňovaly, zda bude ves znovu osazena, či naopak zanikne; 2) di̊sledky válečného plenění v 15. století byly rychle překonávány, obvykle v horizontu 1-2 let a v Chebské pánvi nevedly k pustnutí sidlišt'; 3) jednotlivé pusté usedlosti lze interpretovat jako dlouhodobé sociální úhory, indikujici hospodárské nebo demografické problémy rolnické komunity.
\end{abstract}

Kličová slova: zaniklé středověké vsi-agrárni dějiny - 1400-1500-Chebsko-Bavorsko.

The Processes of Village Abandonment, War Damage and Social Fallows. The Cheb Region in the Late Middle Ages

Abstract: This study sets out to specify findings about the process of village abandonment, the course and impact of local conflicts, and about "social fallows" in the late Middle Ages. The Cheb region was selected for its vast source base in the form of land tax registers (1392-1757). These allow to analyse the socioeconomic, demographic and settlement development of over a hundred villages, year by year. The analysis shows that 1) depopulation was the primary cause of the abandonment process in the late 14th century, possibly triggered by plague epidemics; other factors were of secondary importance, yet on the other hand they also played a part in whether a village would be restored or not; 2) consequences of war damage in the 15th century were quickly overcome, usually within 1-2 years, and in the Cheb Basin they did not result in village abandonment; 3) the individual defunct villages can be interpreted as long-term social fallows indicating economic and demographic problems of farming communities.

Key words: deserted medieval villages - rural history - 1400-1500 - Cheb region - Bavaria.

\section{1 Úvod}

Pustnutí a zanikání sídlišst v pozdním středověku je tradičně považováno za jeden z důležitých barometrů sociálně-ekonomického a demografického vývoje. Velká část interpretačních přístupů naprríč celou Evropou přitom v tomto fenoménu spatřuje nevyhnutelný důsledek depopulace a agrární krize, změn $\mathrm{v}$ zemědělských systémech nebo posunů $\mathrm{v}$ hospodářských zájmech vrchnosti. Environmentálně založení historici zase preferují úvahy o ekologické katastrofě, půdní erozi, minerálním vyčerpání půd a klimatických změnách, které měly vést k rozsáhlému vylidnění zemědělsky méně příhodných oblastí. Oba tyto hlavní interpretační proudy mají v různých regionech tu menší, tu větší uplatnění, zpravidla v souladu s povahou převládající pramenné evidence a školením zainteresovaných badatelů (nověji např. př́spěvky v NocuńFokt-Przybyła-Dumin edd. 2016; Dyer-Jones edd. 2010; Lorenz-Rückert edd. 2009; BeckerEricsson edd. 2004; Felgenhauer-Schmiedt-Csendes-Eibner edd. 2009; Scholkmann et al. edd. 2009; v Čechách nověji např. Klápště 2016, 131-132; dále Fokt 2012, 25-65; ze starší lit. zejména Siedlungsforschung 1994; českou historiografii shrnul Maur 2013, 49-55; Nekuda 1994).

Pomalu se prosazuje také další pohled, k předcházejícím spíše komplementární než alternativní, jenž vychází z přehodnocení tradičních názorů na venkovské prostředí a středověké rolnictvo. To již není vnímáno jako pasivní obět' zhoršených přírodních podmínek, neosobních ekonomických faktorů nebo libovůle vrchnosti, ale naopak jako aktivní tvůrce podoby a fungování svých vlastních komunit (napr. Schofield 2003, 5-8; Alfonso 2007, 8-11; Klír 2008). Některé novější anglické studie, které mohly využít pestř̌jší a detailnější písemnou evidenci, 
spatřují rozhodující př́ičinu pustnutí v dezintegraci rolnických komunit a oslabení vnitřních sociálních vazeb (Dyer 2010). Teprve to mělo umožnit, aby do rozhodování rolníků vůbec vstoupila otázka, zda mají zůstat, či odejít. Až poté, co rolníci ztratili vazby na svůj domov, mohly se uplatnit nepříznivé a lokálně vždy specifické faktory, které dávaly konečný impuls $\mathrm{k}$ tomu, že dlouhodobé existenční strádání, životní těžkosti, nebo jen relativně horší ekonomická bilance vyústily v opuštění vsi. Oslabené a nesoudržné rolnické komunity navíc ztrácely schopnost čelit agresivním ekonomickým praktikám vrchnosti nebo podlehly v konkurenci o př́rodní zdroje s obyvateli ze sousedních sídlišt'.

České středověké prameny dovolují jen vzácně sledovat opouštění vsí jako právě probíhající proces, analyzovat jeho mechanismy a kauzální vztahy. Jakákoliv př́íležitost proniknout za clonu danou nedostatkem pramenů je proto mimořádně cenná, nebot' může významně posunout naše stávající poznání a postoupit od volně formulovaných hypotéz na pevnější půdu faktů. Jednu z možností nabízí bohatě strukturovaná řada rejstř́iků chebské zemské berně, které byly nově zhodnoceny v rámci soustavného výzkumu tohoto regionu (Klír a kol. 2016).

\section{Obecná východiska}

\subsection{Pustnutí versus zánik sídliště}

Každá usedlost čelila přirozeným demografickým a sociálně-ekonomickým cyklům, které byly odděleny náhlými zlomy jako smrtí, svatbou, odvlečením nebo útěkem. Tyto zlomy nemusely být $\mathrm{z}$ rozmanitých prŕíčin ihned překonány a usedlosti zůstávaly různě dlouhou dobu opuštěné nebo jen zčásti využité. Sociální a kulturní geografie proto někdy hovoří o tzv. sociálních úhorech, s nimiž se v dlouhodobém měřítku setkáváme u všech sídlišt' (Freund 1993; Klír 2008, 181-182). Ekonomická úspěšnost sídliště sociální úhory nevylučuje, nebot’ ty závisí i na sociokulturních a demografických faktorech. Přesto lze horší překonávání zlomů a dlouhodobé sociální úhory ve větší míře očekávat u sídlišt' ekonomicky slabších a méně přitažlivých. Pravidlem to však být nemusí (z početné starší literatury zejména Born 1968, 145-146; 1979, 46-48; Ruppert 1958; 1958a; Wendling 1966).

Sociální úhory a pustnutí je třeba striktně odlišit od zániku sídliště. Zatímco sociální úhory jsou přirozenou součástí každého sídelního vývoje a pustnutí je jen jejich dlouhodobá kumulace, zánik je naší umělou poznávací konstrukcí, označující definitivní konec sídelních aktivit. Opuštěná usedlost nebo ves stále přetrvávala jako dočasně neosazená, právně a sociálně-ekonomicky definovaná jednotka, která z pohledu vrchnostenské, církevní i zeměpanské evidence neplnila své povinnosti. Sociální úhor obvykle vystupoval roztroušen a v dlouhodobém pohledu jako by putoval celým sídlištěm. Mohl se však rozšířit i na celé sídliště. Drtivá většina sociálních úhorů byla překonána a mnoho usedlostí a vsí bylo znovu osazeno. Samozřejmě že stanovit ostrou hranici mezi opuštěným a zaniklým sídlištěm je možné jen vzácně. Př́kladem může být formální změna právního rámce, tj. udělení plužiny opuštěné vsi poddaným rolníkům ze sousední vsi, a to nikoliv formou dočasného, ale dědičného nájmu. Raným českým prŕikladem může být osud pusté vsi Truskova u Poběžovic na úpatí Českého lesa roku 1375 (LE I, č. 225, s. 108-109).

$\mathrm{Na}$ otázku, v důsledku jaké události se ves vylidnila a zpustla, lze za př́iznivých okolností najít odpověd'. U otázky, co bylo příčinou zániku, tedy proč ves nebyla znovu osazena a obnovena, to již zpravidla možné není a na tomto místě se jí, pokud možno, vyhneme.

\subsection{Studovaný region}

Předkládaná studie se věnuje poměrně rozsáhlému území, které je mimořádně heterogenní jak z hlediska př́rodních podmínek, tak struktury sídelní sítě a jejího vývoje. Sledovaný okruh s poloměrem až $25 \mathrm{~km}$ od Chebu zahrnuje agroklimaticky ještě poměrně příznivou Chebskou pánev (kolem 450-550 m n.m.) i drsnější horské terény Smrčin, Halštrovských hor a Hornofalckého/Českého lesa (kolem 600-1000 m n.m.). Na části území lze mozaikovitě doložit raně středověké nálezy, sídelní aktivity se nicméně soustředily do nejbližšího okolí Chebu a většina území byla trvale osídlena teprve ve druhé polovině 11. a ve 12. století. Strategický význam 
Chebska plynul z polohy v komunikačním koridoru z Čech do Frank a z Bavorska do Saska, od vrcholného středověku pak rostla úloha Chebské pánve a města Chebu jako hospodářské a organizační základny pro využití nerostného bohatství v přilehlých horských pásmech.

Na tomto místě se nelze detailněji věnovat jednotlivým sídelně-geografickým, sociálně-ekonomickým a historickým aspektům ani konkrétním lokalitám. Pouze pro orientaci přikládáme mapy $\mathrm{s}$ jednoduchým znázorněním reliéfu, historických hranic a pozdně středověkých komunikačních koridorů (obr. 1-2). Pokud jde o základní bilanci prrírodních předpokladů a sídelně-historického vývoje v dnešní české části Chebska, odkazujeme na publikované dizertace R. Käublera (1935) a P. Ettela (2004), pro bavorskou část na dizertaci I. Häuslerové (2004); o archeologických nálezech do 12.-13. století informují studie A. Hejny $(1967 ; 1971)$, na něž nověji navázal J. Hasil (2016; k jazykové situaci srov. Klír 2015; 2016). Detailní historický a topografický přehled je k dispozici v př́íslušných svazcích řady Historischer Atlas von Bayern (Sturm 1970; 1981), jejichž výpověd' doplňují onomastické lexikony (Fischer R. 1940; 1955; Fischer G. 1941; Rogler 1960; Höllerich 1977; Eichler-Hellfritzsch-Richter 1983-1985). Do různé hloubky jsou monograficky zpracovány středověké dějiny města Chebu (zvl. Sturm 1960; 1952; soubor studií Kubů 2006; Klír a kol. 2016, 10-59). Historický přehled vývoje tzv. historického Chebska do

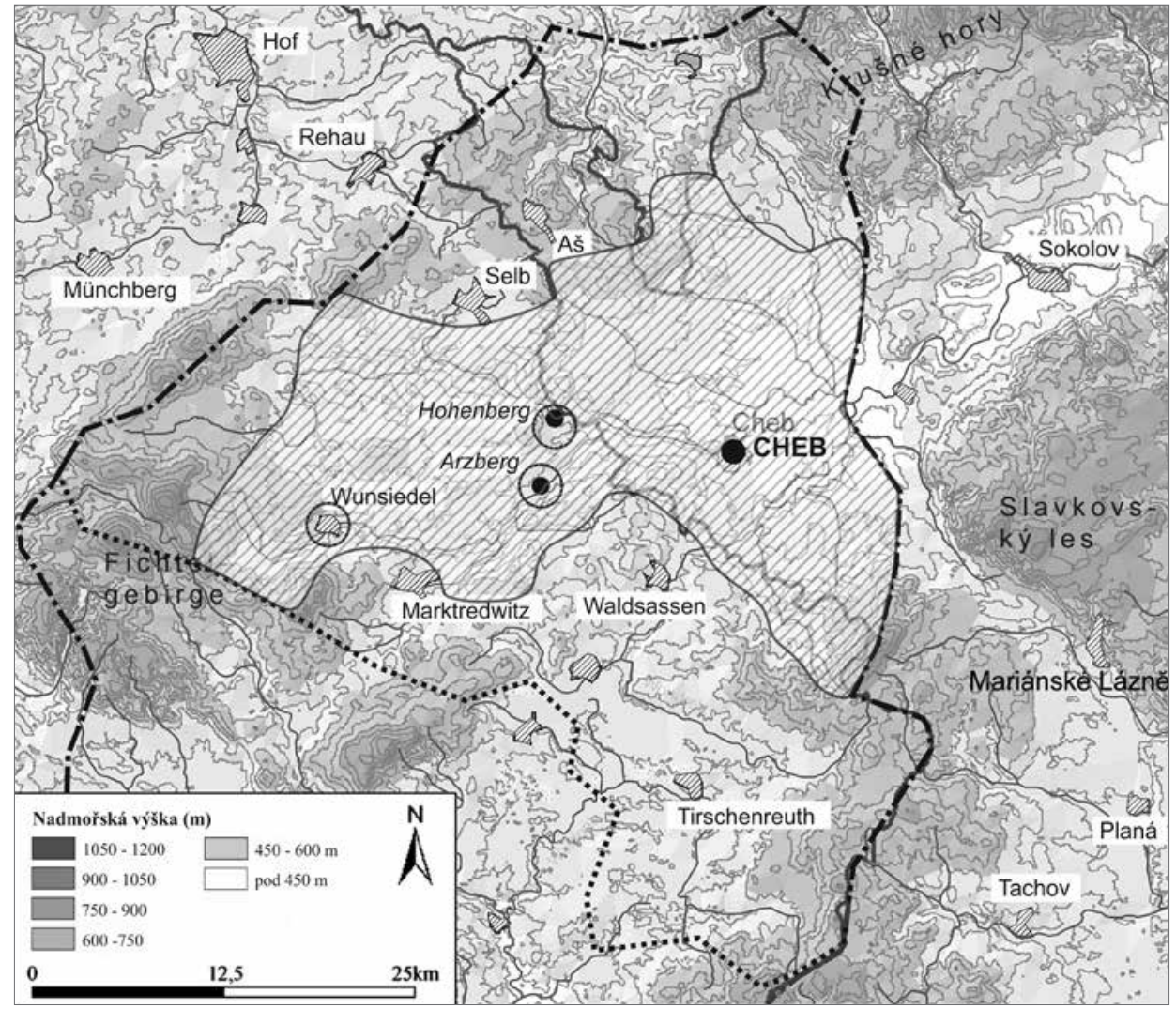

Obr. 1. Vymezení severní části řezenského biskupství (čerchovaná čára) v pozdním středověku, děkanátů Wunsiedel a Cheb roku 1438 (tečkovaná čára, odpovídá tzv. historickému Chebsku podle H. Gradla) a chebské zástavy udělené Ludvíkem IV. Bavorským Janu Lucemburskému v říjnu 1322 (šrafovaně). Převzato z Klír a kol. 2016, obr. 1.

Abb. 1. Abgrenzung des nördlichen Teils des Regensburger Bistums (strichpunktierte Linie) im Spätmittelalter, der Dechanteien Wunsiedel und Eger im Jahr 1438 (punktierte Linie, entspricht laut H. Gradl dem sog. historischen Egerland) und der im Oktober 1322 von Ludwig IV. dem Bayer an Johann von Luxemburg im Oktober 1322 verpfändeten Egerer Gebiete (schraffiert). Entnommen aus Klír a kol. 2016, Abb. 1. 


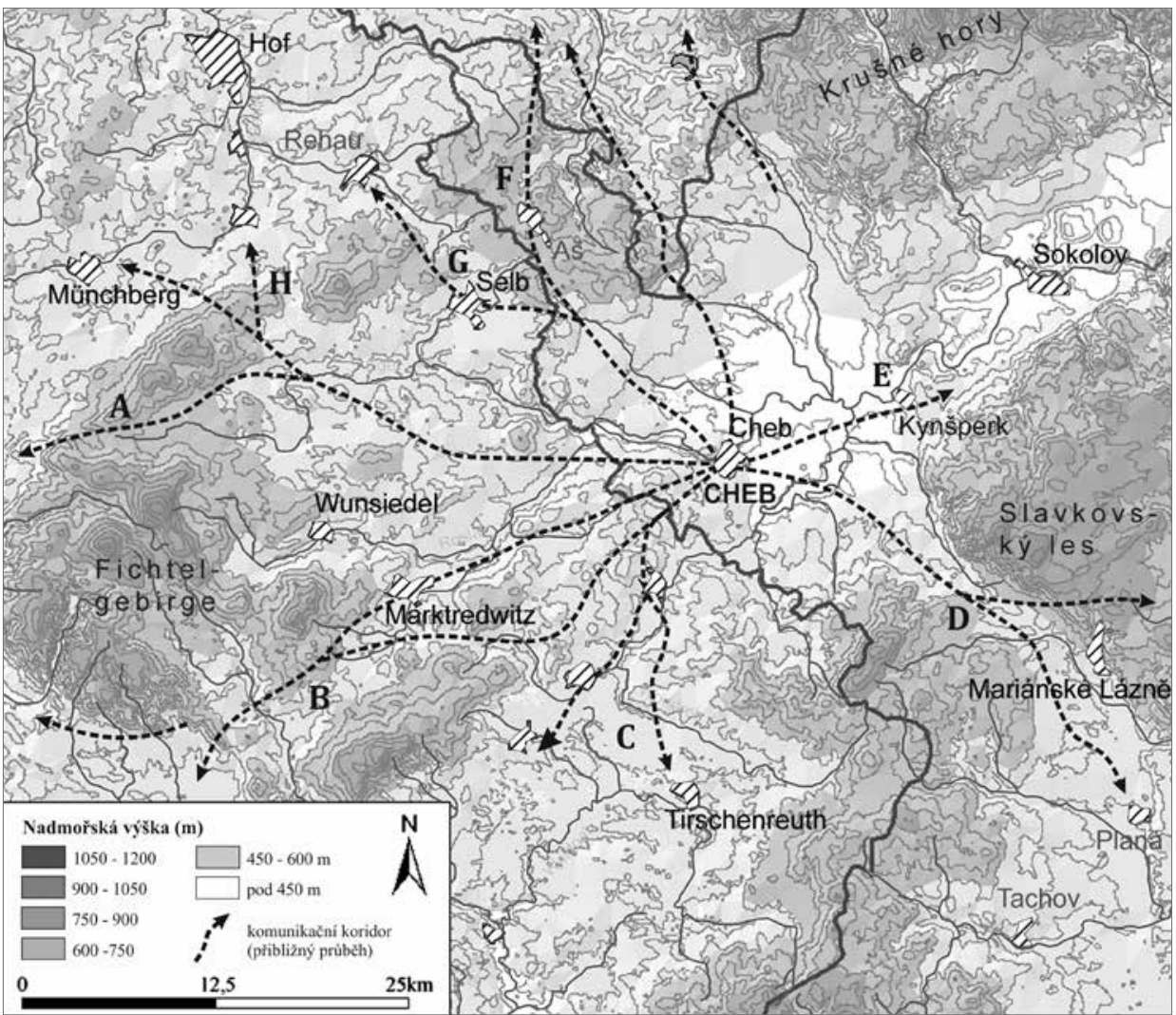

Obr. 2. Komunikační koridory vycházející z Chebu ve vrcholném a pozdním středověku. Průsmyky a brázdy: A - sedlo oddělující prameny Mohanu a Ohře; B - Reslavsko-nábská brázda; C - Nábsko-odravská brázda; D - Žandovský průsmyk; E - průrva mezi Chebskou a Sokolovskou pánví; F - rozvodí Halštrovu, Sály a Ohře; G - sedlo mezi Selbem a Rehau; H - průsmyk podél říčky Lamitz. Podle Klír a kol. 2016, obr. 2.

Abb. 2. Im Hoch- und Spätmittelalter von Eger wegführende Verkehrskorridore. Pässe und Furchen: A - die Quelle des Mains und der Eger trennender Bergsattel; B - Röslau-Naab-Senke; C - Naab-Wondreb-Senke; D - Sandauer Pass; E Kluft zwischen dem Egerer und Falkenauer Becken; F - Wasserscheide der Elster, Saale und Eger; G - Bergsattel zwischen Selb und Rehau; H - Pass entlang des Lamitz-Baches. Nach Klír a kol. 2016, Abb. 2.

roku 1437 podává klasická monografie H. Gradla (1893), pro sálsko-štaufské období je třeba doplnit zejména studii F. Kubů (1997). Rozsáhlá literatura se týká opevněných sídel (např. KnollKarel 2012; Úlovec 1998).

V následujícím textu využijeme především rejstříky chebské zemské berně z let 13921469/1478, které jsou uloženy ve Státním oblastním archivu v Plzni - Státním okresním archivu v Chebu. Z praktických důvodů v textu neuvádíme detailní citaci jednotlivě využitých svazků, z nichž valná část není ani foliována ani paginována, ale odkazujeme na závěrečný seznam pramenů. Transliterace osobních jmen v př́lohách se řídí obvyklými pravidly (srov. Klír a kol. 2016, 284-285, 437-438). Místní jména venkovských lokalit uvádíme v textu v současné úřední podobě, za lomítkem ale doplňujeme standardizovaný historický německý tvar. V tabulkách podle zvyklosti a také s ohledem na přiložené mapy upřednostňujeme historický německý tvar, za nímž uvádíme současný český, pokud existuje (srov. Klír a kol. 2016, 673-682, př́loha 1). 


\subsection{Poddaní a vrchnost}

Analýzu vývoje usedlostí a venkovských sídlišt' je třeba doplnit úvahou o právním postavení poddaných, možnosti jejich svobodného pohybu a povinnostech vůči vrchnosti. Právní rámec poddanské držby na území historického Chebska, ekonomické fungování jednotlivých vrchnostenských statků nebo rozdělení pozemkové držby dosud nebylo soustavně analyzováno, pro základní orientaci proto jen stručně shrnujeme poměry kolem poloviny 15. století (srov. Klír a kol. 2016, 158-161).

Většinu usedlostí na pozdně středověkém Chebsku drželi poddaní zákupním právem, tedy dědičně, pod stálý úročný plat a s možností poměrně volného nakládání. To se odráží v pojmu Kaufrecht a je s tím plně v souladu i výpověd' chebských berních rejstř́iků, které dokládají, že úročné usedlosti byly obvykle předávány z otce na syna, zetě, vdovu, popřípadě prodávány nebo směňovány (k situaci v sousedních Čechách např. Čechura 1990, 485-487, 493-494; Míka 1960, 187-226; Graus 1957, 114-158, 233-267). Výhodnější právní status měla specifická dědičná držba (Erb-), na niž se původně vztahovaly manské povinností. Od poddanských i manských povinností byla osvobozena svobodná držba (frei), která byla zatížena pouze zemskou berní. Do těchto privilegovaných kategorií však náležela jen malá část chebských usedlostí (roku 1469 ca $5-6 \%$ ).

Fixní povinnosti, kterými byli chebští poddaní zatíženi svou vrchností, lze dohledat v berním rejstř́iku z roku 1469 (Klír a kol. 2016, 159-161). Podstatné je, že poddanské povinnosti měly zpravidla podobu úročných platů, roboty nejsou až na jednu výjimku doloženy (Dřenice/Treunitz). Platy byly odváděny většinou v naturáliích, zejména v obilí. Druhou formou dávek byly peněžní platy. Někdy lze sledovat souběh naturálních i peněžních platů v rámci jedné usedlosti.

Absence robotního zatížení dovoluje uvažovat o poměrně rozsáhlé volnosti chebských poddaných, připoutání k půdě nebo sbíhání poddaných není nikde doloženo, chybí institut výhostů (obecně srov. Čechura 1990, 496-497). Poddanská držba byla právně zajištěna a samotné berní knihy dokládají živý transfer půdy, a to zvláště mezi poddanskými usedlostmi ve vsích v blízkosti Chebu nebo podél Ohře ( $\mathrm{k}$ transferu půdy v blízkosti pozdně středověkých měst srov. Cerman 2008, 67-69). Jeden poddaný tak mohl odvádět jeden úročný plat své kmenové vrchnosti a druhý zase vrchnosti jiné za přikoupené pozemky. Pokud můžeme předběžně soudit, vztah poddaný - vrchnost byl na Chebsku poměrně volný a omezoval se většinou jen na odvádění poddanských dávek. O to větší význam měly povinnosti vůči městu Chebu jako faktickému držiteli zeměpanských práv, které byly vyjádřeny placením berně a vojenskou povinností (Klír a kol. 2016, 31-46).

Pro úplnost dodejme, že podle rejstř́ku z roku 1469 byla podstatná část vsí sice majetkově rozdrobena, ale drtivá většina poddaných měla za vrchnost bud' chebské měšt’any (39\%), zejména patricijské rody stojící na pomezí drobné šlechty a vlastnící některé hrady na Chebsku, nebo církevní instituce sídlící ve městě (36\%; blíže Klír a kol. 2016, 159-161).

\section{Prameny - písemnosti chebské zemské berně}

České písemné prameny dovolují jen vzácně sledovat vývoj středověkých venkovských sídlišt' v potřebném detailu (např. Boháč 1983). Urbáře, torzovitě dochované od poslední třetiny 13. století a hojněji teprve od poslední třetiny 14. století, mají normativní povahu a navíc se týkají vždy jen jednoho časového bodu. Aktuální hospodářský a demografický stav poddanských usedlostí reálněji odráží berní a úročné rejstříky, kterých je však k dispozici jen málo a také netvoř́i ucelenou řadu (zejména Graus 1957, 317-356; Nový 1965; 1975; Čechura 1986; 1997). Podobně slabá pramenná evidence pro 14.-15. století přitom není charakteristická jen pro Čechy, ale i pro další sousední historické země. Výjimečné poznávací možnosti, a to i v širším evropském kontextu proto nabízí písemnosti vzniklé v rámci chebského zemského bernictví, nebot' dovolují sledovat zprvu mezerovitě, později rok po roce situaci přibližně tisícovky poddanských usedlostí ve více než stovce vsí (od 1392/1441 do 1757). 
Historické Chebsko, mající od roku 1322 status ř́išské zástavy v rukou českého krále, nebylo dlouho integrováno do českého zemského bernictví. Nicméně zástavní držitel zde vybíral zvláštní zemskou berni zvanou kopytné (Klauensteuer, Klosteuer). Tato berně byla vypisována zprvu jen mimořádně a při jejím výběru kooperovali panovníkovi úředníci s chebskou městskou radou. Na konci 14. století byl již výběr berně plně v rukou městské rady, i když podstatná část z vybrané částky ještě putovala př́mo k panovníkovi. Situace se změnila po roce 1400 , v období válek Václava IV. s protikrálem Ruprechtem Falckým, kdy český král svěřil ochranu Chebska městu Chebu, včetně práva vypisovat a vybírat zemskou berni. $Z$ toho se posléze stala zvyklost, nebot' od roku 1403 začala být berně vybírána víceméně každoročně. Zároveň se zmenšil její geografický dosah. Samostatné zemské bernictví dlouho zůstávalo jedním z výrazných znaků původní chebské autonomie, s níž během tereziánských reforem v 18. století také zaniklo (Klír a kol. 2016, 18, 22, 36-40). Další detaily o genezi zemské berně, proměnách jejího dosahu, zdaňovaných subjektech a objektech, berní sazbě, organizaci bernictví a struktuře dochovaných písemností ponecháváme stranou a odkazujeme na př́íslušnou monografii (Klír a kol. 2016; srov. také Heisinger 1938).

\section{Pustnutí v letech ca 1380-1400}

V nejstarším dochovaném berním rejstříku z roku 1392 bylo různým způsobem evidováno 203 lokalit, některým $\mathrm{z}$ nich ale nebyla berně z různých důvodů předepsána, nebo ji nikdo $\mathrm{z}$ poddaných nezaplatil. $\mathrm{Z}$ mnoha lokalit byla sice předepsaná berně vybrána, ale pouze sumárně, a písař proto ani nezapsal jména jednotlivých platících. Do vnitřní struktury tedy vidíme u 102 lokalit, a i zde je výpověd’ omezená, nebot' evidována nebyla jména všech poplatníků, ale jen skutečně platících (929 jmen). Podobně koncipován byl i berní rejstř́ik z roku 1395 (tab. 1).

\begin{tabular}{|l|c|c|}
\hline Berní rejstř́k & $\mathbf{1 3 9 2}$ & $\mathbf{1 3 9 5}$ \\
\hline Berně předepsána, zaplacena, uvedena jména platících & 102 & 94 \\
\hline Berně předepsána a sumárně zaplacena & 73 & 22 \\
\hline Berně předepsána, ale nikým nezaplacena & 23 & 0 \\
\hline Berně nepředepsána a nezaplacena & 5 & 87 \\
\hline Celkem & $\mathbf{2 0 3}$ & $\mathbf{2 0 3}$ \\
\hline
\end{tabular}

Tab. 1. Zápisy v rejstřících chebské zemské berně z roku 1392 a 1395.

Tab. 1. Einträge in den Egerer Landsteuerbüchern der Jahre 1392 und 1395.

Lokalita neodvádějící předepsanou berni mohla být pustá či ekonomicky slabá, nebo - a to asi nejčastěji - poddané před placením uchránila silná vrchnost. Struktura následujících berních rejstříků z let 1397 až 1409 byla již odlišná, nebot' písaři u žádné z lokalit neuváděli jména platících, ale jen celkově předepsanou sumu a vše doplňovali poznámkou o míře zaplacení. V berním rejstříku z roku 1397 navíc poměrně systematicky označili aktuálně pusté vsi, v čemž pokračovali i v dalších letech, i když již méně soustavněji (Klír a kol. 2016, 74-81, 128-129; Heisinger 1938, 8-14, 105-124).

V berních rejstřících z let 1397-1409 bylo u 36 lokalit alespoň v jednom roce uvedeno, že jsou pusté. Další dvě lokality lze k pustým vsím přiřadit z jiných důvodů. Celkem můžeme posoudit 38 pustých vsí, což představuje přibližně $19 \%$ z celkového počtu lokalit (srov. Klír a kol. 2016, 128-129; Heisinger 1938, 288-295). V tomto souboru jsou interpretačně nejzajímavější ty, u nichž byla roku 1392 nebo 1395 ještě uvedena jména platících (deset lokalit).

Stranou naší analýzy ponecháváme další důležitý pramen osvětlující situaci na chebském venkově roku 1395, a to soupis chebské venkovské hotovosti, nebot' se jen z malé části týká oblasti s pustými sídlišti (srov. Durdík 1966; Kubů 2006, 102-108; Heisinger 1938, 107-124). 


\subsection{Vsi zpustlé kolem roku 1392 a dř́ve}

Již první pohled do přehledových tabulek ukazuje, že berní rejstř́íky z let 1392-1409/1424 zachycují dynamický sídelní vývoj. Mnoho sídlišst již bylo pustých, další se právě vylidňovala, ale zároveň probíhal i opačný proces a sídliště znovu ožívala.

Jako první můžeme vyčlenit skupinu 17 lokalit, které byly víceméně opuštěné již k roku 1392, nebot' berně jim toho roku byla sice předepsána, ale nikdo ji nezaplatil. Podobně tomu bylo roku 1395 a do rejstř́ku z roku 1397 k jejich jménům písaři poznamenali, že jsou aktuálně pusté (,,czu der czeit wueste“). Označení „wüst“/,wust“" se pak opakovalo i v následujících letech (tab. 2, č. 1-17). Tuto skupinu lze rozšířit ještě o další dvě sídliště označovaná jako pustá, z nichž byla $v$ jednom roce vybrána alespoň část berně (tab. 2, č. 18-19). Většina $\mathrm{z}$ těchto lokalit ležela na přechodu Smrčin a Halštrovských hor, tedy v okolí Selbu, Aše a Brambachu (obr. 3; srov. Klír a kol. 2016 - mapy na přídeštích). Několik z nich bylo ještě během 15. století bud' obnoveno, nebo se na jejich místě udrželo alespoň sídelní reziduum (šest př́ípadů; např. Wildenau, nově osazeno k roku 1424; k tomu také Klír a kol. 2016, 130, prŕíloha 10a).

\begin{tabular}{|c|c|c|c|c|c|c|c|c|c|}
\hline & Současné místní jméno & 1392 & 1395 & 1397 & 1401 & 1404 & 1408 & 1409 & 1424 \\
\hline 1 & - Wintersreuth $(\mathrm{N})$ & 5 gr.* & - & + & + & + & + & + & + \\
\hline 2 & Eulenhammer (N) & 7 gr.* & - & + & + & + & + & + & + \\
\hline 3 & • Zwerkengrün $(\mathrm{N})$ & 27 gr.* & - & + & + & + & + & + & - \\
\hline 4 & • Reitenbach $(\mathrm{N})$ & 36 gr.* $^{*}$ & - & + & + & + & + & + & chybí \\
\hline 5 & - Haidholz & 38 gr.* & - & + & + & + & + & + & + \\
\hline 6. & • Bärendorf $(\mathrm{N})$ & 41 gr.* & - & + & + & + & + & + & - \\
\hline 7 & Elfhausen & 45 gr.* $^{*}$ & - & + & + & + & + & + & + \\
\hline 8 & • Rebersreuth u Schönwaldu (N) & 47 gr.* & - & + & + & + & + & + & chybí \\
\hline 9 & - Rebersreuth u Wernersreuthu (N) & 47 gr.* & - & + & + & + & + & + & chybí \\
\hline 10 & • Thonbrunn $(\mathrm{N})$ & 47 gr.* $^{*}$ & - & + & + & + & + & + & + \\
\hline 11 & - Haselbach (N) & 55 gr.* & - & + & + & + & + & + & - \\
\hline 12 & Mähring & $1 \beta 3$ gr.* & - & + & + & + & + & + & + \\
\hline 13 & Wildenau $(\mathrm{N})$ & $1 \beta 7$ gr.* & - & + & + & + & + & + & + \\
\hline 14 & • Röthenbach u Brambachu (N) & $1 ß 12$ gr.* & - & + & + & + & + & + & chybí \\
\hline 15 & Reuth (Ober-)/ Horní Paseky & $1 B 30$ gr.* & - & + & + & + & + & + & \\
\hline 16 & Schildern/Štítary & $1 ß 3$ gr.* & - & + & + & + & + & + & \\
\hline 17 & - Brambach (Ober-) (N) & $2 \beta 15$ gr.* & - & + & + & + & + & + & - \\
\hline 18 & Erkersreuth $(\mathrm{N})$ & 2 B 24 gr.* & - & + & $\begin{array}{c}3 \beta \\
(25 \mathrm{gr} .)\end{array}$ & + & + & + & + \\
\hline 19 & • Schönlind u Selbu (N) & 47 gr.* & - & $\begin{array}{c}2 \beta 4 \\
\text { gr. }\end{array}$ & + & + & $1 \beta 3$ gr. (0) & $\begin{array}{c}1 \beta 3 \\
\text { gr. }(0)\end{array}$ & + \\
\hline 20 & - Mitterwald & - & - & $1 \beta$ & $20 \mathrm{gr}$. & $20 \mathrm{gr}$. & $\begin{array}{l}20 \text { gr. }(17 \\
\text { gr.) }\end{array}$ & $20 \mathrm{gr}$. & - \\
\hline 21 & • Hilpersgrün & $18 \mathrm{gr}$. & 54 gr. & $45 \mathrm{gr}$. & $30 \mathrm{gr}$. & $30 \mathrm{gr}$. & $30 \mathrm{gr}$. & $30 \mathrm{gr}$. & chybí \\
\hline
\end{tabular}

Tab. 2. Sídliště neplatící berni v letech 1392 a 1395, která byla v letech 1397-1409/1424 zároveň označena jako pustá. Podle příslušných čistopisů rejstříků chebské zemské berně. Srov. obr. 3 a Klír a kol. 2016 - mapy na přídeštích. •-ves neobnovená a dnes zaniklá, bez sídelního rezidua; + - v berním rejstř́íku ves označena jako pustá; * - z předepsané berně nebylo nic nezaplaceno; B - kopa grošů pražských; gr. - pražský groš; (N) - lokalita na území Spolkové republiky Německo; ,-“-v rejstř́íku uvedeno pouze jméno lokality; „,chybí“ - berní rejstř́ik z roku 1424 se dochoval pouze v torzu, listy s některými lokalitami proto chybí.

Tab. 2. Siedlungen, die in den Jahren 1392 und 1395 keine Steuern entrichteten und in den Jahren 1397-1409/1424 gleichzeitig als wüst bezeichnet wurden. Gemäß den einschlägigen Reinschriften der Egerer Landsteuerbücher. Vgl. Abb. 3 und Klír a kol. 2016 - Karten auf den Vorsatzblättern. • - nicht wieder aufgebautes und heute wüstes Dorf, ohne Siedlungsresiduen; + - im Steuerbuch als wüst bezeichnetes Dorf; * - von der vorgeschriebenen Steuer wurde nichts entrichtet; $\beta$ - Schock Prager Groschen; gr. - Prager Groschen; (N) - Fundstelle auf dem Gebiet der Bundesrepublik Deutschland; ,-“" - im Steuerbuch wird lediglich der Name des Ortes aufgeführt; „chybi“ - das Steuerbuch aus dem Jahr 1424 ist lediglich als Torso erhalten geblieben, weswegen Blätter mit einigen Orten fehlen. 


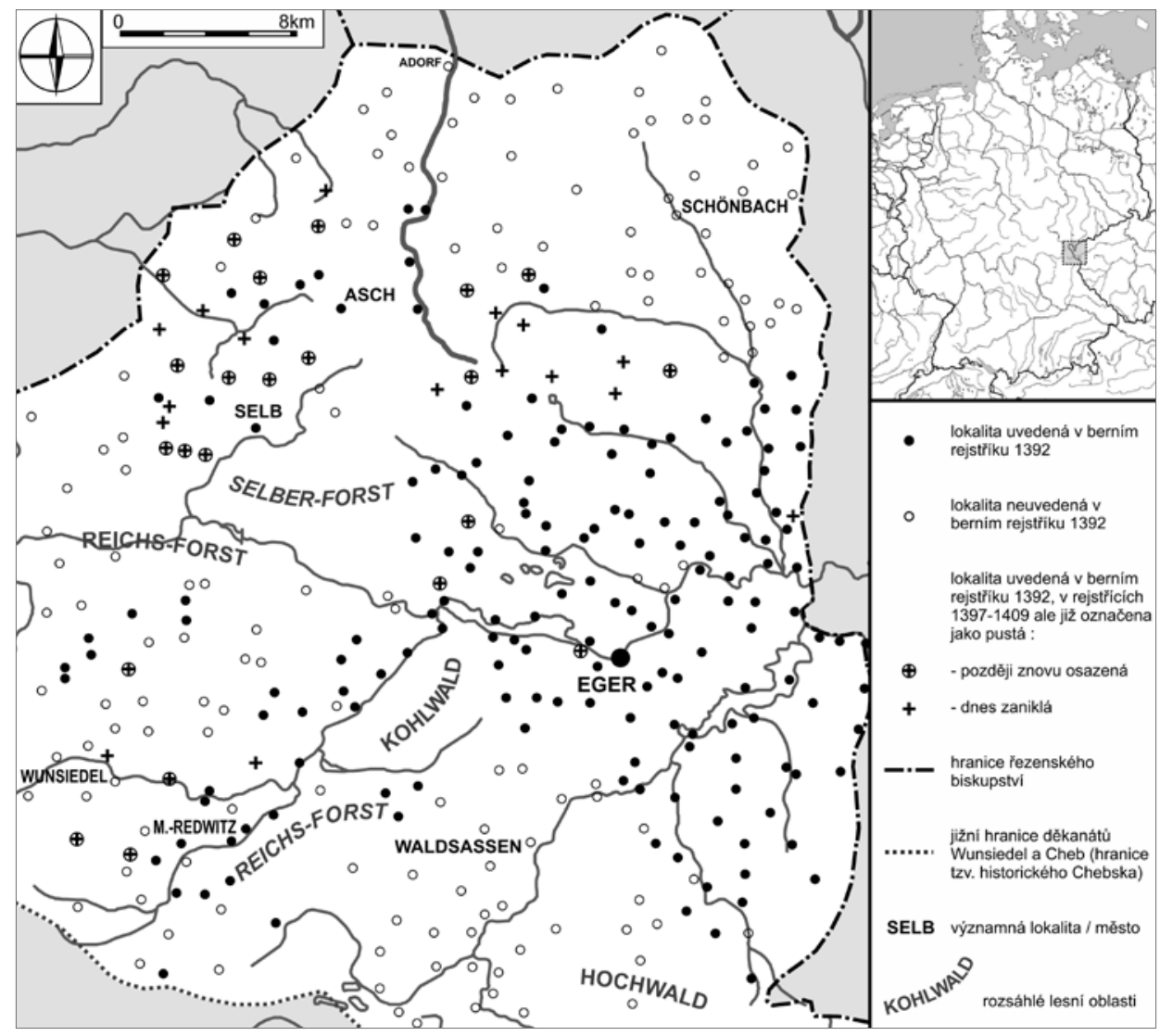

Obr. 3. Vsi uvedené v berním rejstríku z roku 1392. Ze zaniklých vsí nezobrazeny nelokalizovaný Rebersreuth u Wernersreuthu. Oblast mimo tzv. historické Chebsko nesledována.

Abb. 3. Im Steuerbuch von 1392 aufgeführte Dörfer. Von den Dorfwüstungen wird das nicht lokalisierte Dorf Rebersreuth bei Wernersreuth nicht abgebildet. Das Gebiet außerhalb des sog. historischen Egerlandes blieb unberücksichtigt.

Jako sídliště vylidněná ještě před roku 1392 lze interpretovat další dvě lokality, které sice nebyly v rejstř́ících z let 1397-1409/1424 označovány jako pusté, ale jejichž pozemky podle pozdějších berních rejstříků užívali poplatníci z okolních vsi a platili z nich také zemskou berni (srov. Klír a kol. 2016, rejstř́k). Prvá z těchto lokalit ležela v Halštrovských horách u Skalné/Wildstein (Mitterwald), druhá na východním okraji Chebské pánve při úpatí Krušných hor (Hilpersgrün; tab. 2, č. 20-21).

Velikost a ekonomickou situaci pustnoucích sídlišt' lze odvodit z výše celkově předepsané berně, nebot' ta byla stanovena na základě peněžní hodnoty majetku poplatníků. Podle ní a také podle podoby místního jména můžeme identifikovat jednu samotu (Eulenhammer) a jednu ves, která se jeví jako vylidněná, nebot' jí byla vyměřena jen minimální berně 5 grošů (Wintersreuth). Na pozadí Chebska jako celku (graf 1) lze dále vyčlenit rozsáhlou skupinu sídlišst', jejichž berní povinnost patřila rovněž mezi nejnižší, bud' kvůli nízkému počtu usedlostí, nebo hospodářským potížím, poprrípadě z obou důvodů (berně ve výši kolem půl až jedné kopy grošů). Jen tři z celkem 19 posuzovaných sídlišt' se přiblížila alespoň širšímu chebskému průměru, nebot' jim byla předepsána berně ve výši jedna a půl až dva a půl kopy grošů (Horní Paseky/Ober-Reuth, Ober-Brambach a Erkersreuth). 


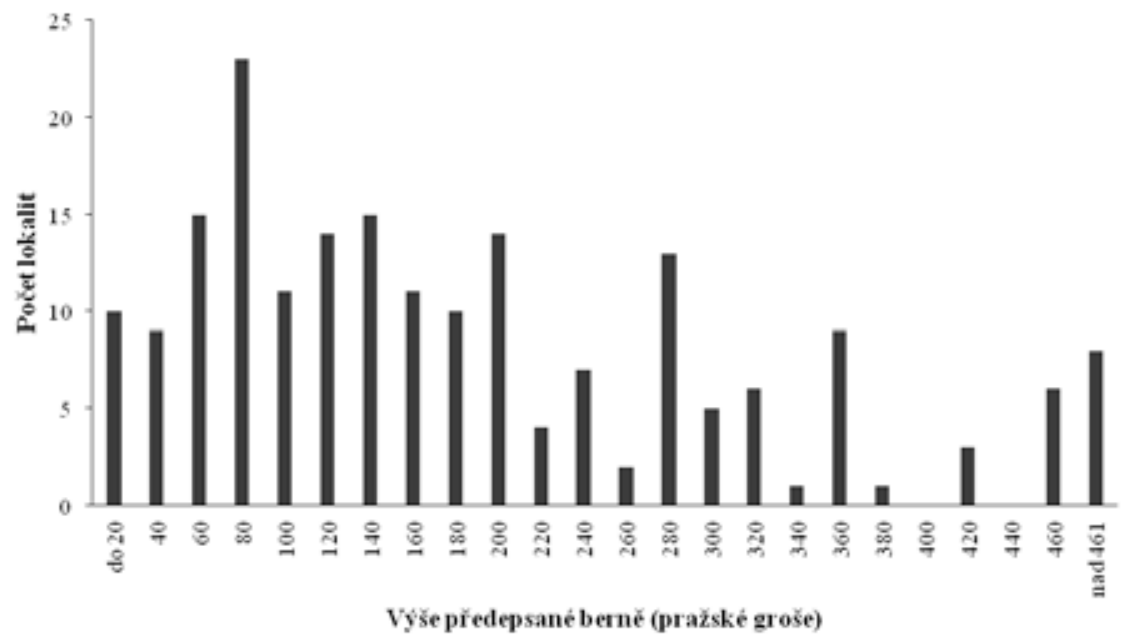

Graf 1. Výše zemské berně předepsaná lokalitám jako celku roku 1392. Podle čistopisu př́íslušného berního rejstříku. Srov. také Heisinger 1938, Tabelle 1.

Diagramm 1. Höhe der Landsteuer, die den Orten als Gesamtheit im Jahr 1392 vorgeschrieben wurde. Laut der Reinschrift des einschlägigen Steuerbuchs. Vgl. auch Heisinger 1938, Tabelle 1.

K přesné chronologii pustnutí dané skupiny 19 sídlišt' se nelze vyjádřit, nebot' nevíme, zda písaři do rejstř́íku z roku 1392 nepřepsali neaktuální údaje z nějaké starší předlohy. V každém případě vylidnění těchto sídlišt' - pozorovatelné již roku 1392 - bylo dokonáno nejpozději k roku 1397. Zároveň lze předpokládat, že ještě v 70.-80. letech 14. století se v nich nacházela jedna či více osazených usedlostí.

\subsection{Vsi zpustlé po roce 1392/1395}

Mezi sídlišti, jež roku 1392 nebo 1395 odvedla alespoň část předepsané berně, můžeme vyčlenit vylidněné vsi Bernstein a Reichenbach u Selbu, kde formálně přetrvávaly jen mlýny, ale i z nich přstala být berně brzy placena a získaly označení pusté (tab. 3, č. 1-2).

Další skupinu představuje sedm sídlišt', která roku 1392 nebo 1395 berni odvedla, ale již roku 1397 byla označena jako pustá a toto označení jim nadále zůstalo (tab. 3, č. 3-7). Roku 1408 se k nim přidal ještě Weißenbach u Brambachu. Hůře lze posoudit vývoj v pustých vsích Korbersdorf a Meußelsdorf u Wunsiedelu, které patřily norimberským purkrabím, což snižuje výpověd' chebské berní evidence. Do poslední skupiny řadíme pět vsí, které byly označeny jako pusté pouze v roce 1397, ale poté berni již bez výpadku opět odváděly. V jejich případě můžeme uvažovat o náhlém vylidnění a krátkodobých sociálních úhorech, které byly záhy překonány (tab. 3, č. 13-17).

Velikost a ekonomickou sílu pěti sídlišt' nejsme schopni posoudit, nebot' ani jeden rejstřík nezaznamenal jednotlivé platící. V některých případech tušíme spíše malá nebo vylidněná sídliště (Korbersdorf, Meußelsdorf, Hohendorf), za jinými se skrývaly rozsáhlé vsi odvádějící mimořádně vysokou berni (Bernstein u Wunsiedelu, Weißenbach u Brambachu).

Obraz konkretizují až lokality, u nichž známe jak výši berně, tak počty a jména platících. Nacházíme mezi nimi drobná sídliště se dvěma až pěti platícími i skutečné vsi s osmi až čtrnácti platícími. Pozoruhodná byla ves Limberg, z níž roku 1395 berni v plné výši odvedlo čtrnáct platících, včetně rychtáře. Přesto byla o dva roky později vedena jako pustá a při tom již navždy zůstalo. Podobně tomu bylo ve vsi Táborské/Seichenreuthu s devíti poplatníky, u které roku 1395 nenacházíme žádné krizové příznaky, o dva roky později ale byla rovněž náhle pustá. Jen o trochu pomaleji se vylidňovaly Thölau a Klein-Wendern u Wunsiedelu a Schönwald u Selbu. 
Krizovou situaci nacházíme v Plößbergu u Selbu a v Grünu u Hazlova. V Plößbergu lze mezi sedmi platícími identifikovat tři vdovy, ve vsi tedy chyběli dospělí synové nebo o převzetí usedlostí nebyl prŕliš velký zájem (srov. Klír 2008, 184). V Grünu klesl počet platících z devíti roku 1392 na jednoho roku 1395. S posouzením Křižovatky/Klinghart váháme.

Některá sídliště zpustlá kolem let 1395-1397 byla poměrně rychle znovu osazena a existují dodnes. Pokud jejich vrchnost uznala zástavního držitele Chebska, začala tato sídliště odvádět také zemskou berni, a nacházíme je tak opět v rejstř́ících (tab. 3, č. 13-17). Jestliže ne, obnovení

\begin{tabular}{|c|c|c|c|c|c|c|c|c|c|c|}
\hline & $\begin{array}{c}\text { Současné místní } \\
\text { jméno }\end{array}$ & 1392 & 1395 & $\begin{array}{c}\text { Počet } \\
\text { platících }\end{array}$ & 1397 & 1401 & 1404 & 1408 & 1409 & 1424 \\
\hline 1 & Reichenbach (N) & - & - & - & $\begin{array}{l}3 \text { gr. } \\
\text { mlýn }\end{array}$ & 2 gr. mlýn & $\begin{array}{l}2 \text { gr.* } \\
\text { mlýn }\end{array}$ & $\begin{array}{c}+ \\
\text { mlýn }\end{array}$ & $\begin{array}{l}+ \\
\text { mlýn }\end{array}$ & chybí \\
\hline 2 & Bernstein u Selbu (N) & $\begin{array}{c}18 \text { gr. } \\
\text { (mlynáŕ) }\end{array}$ & - & $1(1392)$ & + & + & + & + & + & + \\
\hline 3 & Wendern (Klein-) $(\mathrm{N})$ & $1 \beta 12$ gr.** $^{*}$ & 3 B $36 \mathrm{gr}$. & $2(1395)$ & $\begin{array}{c}2 \beta 24 \\
\text { gr. }\end{array}$ & $1 \beta 3$ gr.* & + & + & + & - \\
\hline 4 & Schönwald (N) & $1 ß 30$ gr. & - & $5(1392)$ & $36 \mathrm{gr}$. & + & + & + & + & - \\
\hline 5 & - Hohendorf $(\mathrm{N})$ & 1 B 30 gr.* & - & $?$ & + & + & + & $-(\mathrm{F})$ & $-(\mathrm{F})$ & $-(\mathrm{F})$ \\
\hline 6 & $\begin{array}{l}\text { Grün u Hazlova)/ } \\
\text { Výhledy (?) }\end{array}$ & $2 \beta 15$ gr. & $\begin{array}{l}6 \text { B } 45 \text { gr. } \\
\text { (37,5 gr.) }\end{array}$ & $\begin{array}{l}9(1392) \\
1(1395)\end{array}$ & + & + & + & + & + & + \\
\hline 7 & Plößberg (N) & $2 \beta 33$ gr. & - & $7(1392)$ & + & + & + & + & + & - \\
\hline 8 & $\begin{array}{l}\text { Bernstein (N) } \\
\text { u Wunsiedelu }\end{array}$ & $3 ß$ gr.** & - & $?$ & + & + & + & - & - & - \\
\hline 9 & - Limberg & $3 ß$ gr.** & $9 \beta$ gr. & $14(1395)$ & + & + & + & + & + & + \\
\hline 10 & $\begin{array}{l}\text { Weißenbach (Ober-, } \\
\text { Unter-) }(\mathrm{N})\end{array}$ & $\begin{array}{l}7 \text { B } 36 \text { gr.** } \\
\text { (7 ß gr.) }\end{array}$ & - & $?$ & $3 B$ & $2 \beta$ & $2 \beta^{*}$ & + & + & - \\
\hline 11 & - Korbersdorf $(\mathrm{N})$ & $36 \mathrm{gr}^{* *}$ & - & $?$ & + & $\begin{array}{c}1 \beta 12 \text { gr.* } \\
\text { (P) }\end{array}$ & $\begin{array}{c}1 \mathrm{~B} \\
12 \text { gr.* } \\
\text { (P) }\end{array}$ & $\begin{array}{c}1 \beta 12 \\
\text { gr.* } \\
\text { (P) }\end{array}$ & $-(\mathrm{P})$ & chybí \\
\hline 12 & Meußelsdorf (N) & $1 \beta 7 \mathrm{gr}^{* *}$ & $\begin{array}{c}3 \beta \\
26 \text { gr.** }^{* *}\end{array}$ & $?$ & $\begin{array}{c}1 \beta 36 \\
\text { gr.* } \\
\text { (P) }\end{array}$ & $\begin{array}{l}2 \beta 6 \text { gr.* } \\
\text { (P) }\end{array}$ & $\begin{array}{c}2 \beta \\
6 \text { gr.* } \\
\text { (P) }\end{array}$ & $-(\mathrm{P})$ & $-(\mathrm{P})$ & + \\
\hline 13 & $\begin{array}{l}\text { Tobiesenreuth/ } \\
\text { Dobrošov }\end{array}$ & $\begin{array}{l}54 \text { gr. } \\
\text { (46 gr.) }\end{array}$ & - & $4(1392)$ & + & $\begin{array}{c}1 \beta 12 \mathrm{gr} . \\
(1 \beta)\end{array}$ & $1 B$ & $\begin{array}{c}1 \beta(46 \\
\text { gr.) } \\
(\mathrm{K})\end{array}$ & $\begin{array}{c}1 \beta \\
(40 \text { gr. }) \\
(\mathrm{K})\end{array}$ & $1 \beta$ \\
\hline 14 & Kreutzenstein/Skalka & $1 ß 3 \mathrm{gr}$. & - & $3(1392)$ & + & $\begin{array}{l}1 \text { B } 24 \text { gr. } \\
\text { (51,5 gr.) }\end{array}$ & $\begin{array}{c}1 \beta \\
24 \mathrm{gr} .\end{array}$ & $\begin{array}{c}1 \beta 24 \\
\text { gr. }\end{array}$ & $\begin{array}{c}1 \beta \\
24 \mathrm{gr} .\end{array}$ & $\begin{array}{c}7 \mathrm{~B} \\
24 \mathrm{gr} .\end{array}$ \\
\hline 15 & Seichenreuth/Táborská & $\begin{array}{l}2 \beta 42 \text { gr. } \\
(2 \& 26 \text { gr.) }\end{array}$ & $\begin{array}{l}8 \text { B } 6 \text { gr. } \\
(6 B 57 \text { gr. })\end{array}$ & $\begin{array}{l}8(1392) \\
9(1395)\end{array}$ & + & $3 \beta 6 \mathrm{gr}$. & $\begin{array}{c}3 \beta \\
6 \mathrm{gr} .\end{array}$ & $\begin{array}{c}3 \beta 6 \\
\text { gr. }\end{array}$ & $\begin{array}{l}3 \beta \\
6 \text { gr. }\end{array}$ & $\begin{array}{c}3 \mathrm{~B} \\
14 \mathrm{gr} .\end{array}$ \\
\hline 16 & $\begin{array}{l}\text { Thölau (Ober-, Unter-) } \\
\text { (N) }\end{array}$ & $3 ß$ gr.** & $9 \beta \mathrm{gr}$. & $12(1395)$ & $1 \beta /+$ & + & $\begin{array}{c}1 \beta \\
(35 \text { gr. })\end{array}$ & $1 B$ & $1 \beta^{*}$ & $1 B$ \\
\hline 17 & Klinghart/Křižovatka & $4 ß 48$ gr.** & $\begin{array}{l}14 \text { B } 24 \text { gr. } \\
\text { (6 B } 26 \text { gr.) }\end{array}$ & $9(1395)$ & $+(3 \beta)$ & $2 \beta$ & $2 \beta$ & $2 \beta$ & $\begin{array}{l}2 \beta \\
(1 \beta)\end{array}$ & chybí \\
\hline
\end{tabular}

Tab. 3. Sídliššě platící berni roku 1392 nebo 1395 a později uvedená jako pustá. Roku 1395 byla poplatníkům vyměřena trojnásobně vysoká berně ve srovnání s rokem 1392. Podle příslušných čistopisủ rejstř́íkủ chebské zemské berně. Srov. obr. 3 a Klír a kol. 2016 - mapy na přídeštích. • - ves neobnovená a dnes zaniklá, bez sídelního rezidua; + - v berním rejstř́íku ves označena jako pustá; * $\mathrm{z}$ předepsané berně nic nezaplaceno; ** jména platících neuvedena; $(\ldots)-$ předepsaná berně zaplacena jen zčásti, skutečná platba uvedena v závorce; ,-“- - v rejstř́íku uvedeno jen jméno lokality; „chybí“-berní rejstř́k z roku 1424 se dochoval pouze v torzu, listy s některými lokalitami proto chybí. Neplatící poddaní vrchnosti: F - fojtové z Plavna; K - Kropfové; $P$ - purkrabí norimberští.

Tab. 3. Siedlungen, die im Jahr 1392 oder 1395 Steuern entrichteten und später als wüst aufgeführt werden. Im Jahr 1395 wurde den Abgabepflichtigen im Vergleich zum Jahr 1392 eine dreimal höhere Steuer bemessen. Gemäß den einschlägigen Reinschriften der Egerer Landsteuerbücher. Vgl. Abb. 3 und Klír a kol. 2016 - Karten auf den Vorsatzblättern. - - nicht wieder aufgebautes und heute wüstes Dorf, ohne Siedlungsresiduen; +-im Steuerbuch als wüst bezeichnetes Dorf; * - von der vorgeschriebenen Steuer wurde nichts entrichtet; ** - die Namen der Abgabepflichtigen werden nicht aufgeführt; (...) - die vorgeschriebene Steuer wurde nur teilweise entrichtet, die tatsächliche Zahlung wird in Klammern angegeben; "-“-im Steuerbuch wird lediglich der Name des Ortes aufgeführt; „chybí“- das Steuerbuch aus dem Jahr 1424 ist lediglich als Torso erhalten geblieben, weswegen Blätter mit einigen Orten fehlen. Nicht Abgabepflichtige der Obrigkeit: F - Vögte aus Plauen; K - Familie Kropf; P - Nürnberger Burggrafen. 
vsí po roce 1409 nedokážeme s jistotou sledovat. Definitivně a bez rezidua zanikly pouze tř́i vsi - Limberg, Korbersdorf a Hohendorf.

Pokud jde o prostorové rozvržení, posuzovaná pustá sídliště ležela ve Smrčinách a Halštrovských horách, některá se přiblížila až k okrajům Chebské pánve (obr. 3; srov. Klír a kol. 2016 - mapy na př́ideštích).

\subsection{Pustnutí na pozadí extrémní mortality}

Rejstř́ky chebské zemské berně z let 1392-1409/1424 odpovídají jednomu z hlavních modelových schémat pustnutí vsí v pozdním středověku. Spouštěcím mechanismem byla extrémně vysoká úmrtnost, v jejímž důsledku se náhle uvolnilo velké množství usedlostí. Vylidnění některých vsí mohla prohloubit zvýšená mobilita poddaných, díky které byly usedlosti v některých vsích zase rychle osazeny, pro jiné to ale naopak znamenalo období dlouhodobých sociálních úhorů (srov. Maur 1989, 42-52). Na Chebsku přitom vidíme zřetelnou zonaci korelující s přírodními a také odbytovými podmínkami. Nejdříve pustly vsi v agroklimaticky nepř́znivých Halštrovských horách, následovaly Smrčiny u Wunsiedelu (80. léta 14. století) a o několik let později se pustnutí rozlilo i do nižších poloh a přiblížilo se k Chebské pánvi (90. léta 14. století). Zároveň platí, že vsi vylidněné nejpozději byly v období obnoveného populačního růstu po roce 1400 obvykle znovu osazeny, naopak ty nejdříve opuštěné často definitivně zanikly.

Nápadně rychlé vylidnění poměrně velkých vsí v 80 .-90. letech 14 . století, téměř z roku na rok, lze na Chebsku vysvětlit nejlépe demografickou krizí vyvolanou morovými vlnami. O rozsáhlejším a plošném válečném plenění nebo jiné katastrofické události chybí doklady (srov. Gradl 1893, zvl. 261-292). Jako pustá a vypálená se v rejstř́íku z roku 1397 uváděla pouze Křižovatka/Klinghart. Samozřejmě označení, že ves je pustá, ještě nemuselo znamenat absolutní vylidnění (k českým pramenům nap̌r. Boháč 1983, 271-274).

Pokud jde o vsi jako Limberg, Thölau a Táborská/Seichenreuth, naši pozornost přirozeně poutá rok 1395, s nímž je spojována jedna z výrazných morových ran ve střední Evropě, doložená rovněž v Čechách a Frankách (Maur 1989, 32; Bauernfeind 1993, 160-161). Výši tehdejší mortality indikují také rejstř́íky chebské městské berně. Zatímco nejstarší dochovaný rejstř́ik z roku 1390 evidoval 1306 , poprrípadě 1331 poplatníků, tak rejstř́ik z roku 1396 jen 964. S jistou rezervou si lze proto představit, že téměř $30 \%$ městských domácností vymřelo, skutečná mortalita byla tedy patrně ještě vyšší (srov. Klír a kol. 2016, 46-48; ke kritickému vyhodnocení městských sbírek srov. Nodl 2000, 12-18).

Venkovská sídliště na Chebsku sledovala trajektorii, kterou v konkrétnějších obrysech známe z nedalekých Frank. Zatímco první morové vlny po roce 1347/1349 venkov ještě nijak dramaticky nevylidnily a byly překonány, jinak tomu bylo za velkého moru v letech 1377-1383. Na Norimbersku, pro které situaci známe nejlépe, se po roce 1379 dramaticky změnily odbytové podmínky pro zemědělské produkty, dlouhodobý růst obilních cen vystřídal jejich extrémní propad a stagnace, počet usedlostí na venkově klesl v průměru o $20 \%$ a množství produkovaného obilí dokonce až o 50\%. Do období let 1387-1389 je pak kladen propad na dno pozdně středověkého demografického vývoje, nebot' důsledky negativních tendencí znásobily ještě lokální války vedené říšskými městy a utlumené teprve říšským sněmem v Chebu roku 1389. Populační a agrární růst lze opět doložit až od konce 90 . let 14. století a v prvních dvou desetiletích 15 . století (Bauernfeind 1993, 98-177, 355-357).

Spojitost rozsáhlého pustnutí venkovských sídlišt' a morové vlny z let 1377-1383 je písemnými prameny dobře dokumentována i pro jiné německé regiony (např. Rubner 1964, 441; Hoffmann 1981). V Čechách není pochyb o podobně extrémní mortalitě, její sídelní důsledky jsou ale dosud spíše jen odhadovány (Maur 1989, 26-31, 40-41, 46-47; k dopadu mortalitních krizí skepticky např. Čechura 1987; 1994, 286-303; srov. také Nodl 1994, 7-14; 2000, 15-16).

Vlastní Chebské pánvi se pustnutí víceméně vyhnulo a depopulace byla překonána, o to více však zpustly přilehlé pahorkatiny a horské regiony. Tento trend potvrzují rovněž nejstarší lenní knihy leuchtenberských markrabí sestavené v letech 1396-1399, jež zmiňují velké množství již tehdy pustých vsí ve Slavkovském a Hornofalckém lese (Völkl ed. 1955; srov. Velička 
2014). Relikty některých z těchto vsí byly také moderně dokumentovány (Klír 2010, obr. 3-5; Klír-Kenzler 2009). Podobný obraz hromadného pustnutí někdy po roce 1370, nejpozději však po roce 1380 bychom mohli sestavit i pro přilehlé části Horní Falce, Frank, Saska i blízkého Durynska (na základě písemných pramenů napřr. Leingärtner 1956, 36-37; Müller 1951; Barth 1949; z pohledu archeologie Kenzler 2012, 74-82; Becker-Ericsson edd. 2004).

Shrneme-li dosavadní poznatky, pustnutí vsí v námi sledovaném časovém úseku bylo iniciováno mortalitní krizí. To ale nijak nesnižuje váhu ostatních faktorů, jako byly přírodní podmínky, působení trhu, zájmy vrchnosti či soudržnost rolnické komunity, nebot’ ty jako celek do velké míry určovaly, zda bude ves obnovena, nebo naopak zanikne.

\section{Pohromy a sociální úhory}

Řadu rejstř́íků chebské zemské berně přerušuje dlouhá mezera mezi lety 1409 (popř̀. ca 1410) a 1424. Od roku 1424 měly rejstř́ky jinou strukturu, evidovaly již jména všech poplatníků, a jejich výpověd' je proto výrazně detailnější. V rejstřících z let 1424 a 1438 se navíc dochoval popis zdaňovaných položek, pro rok 1456 je k dispozici i speciální oceňovací kniha (Klír a kol. 2016, 74-118, 135-157). Zároveň se zmenšil geografický dosah zemské berně, a to na území dnešního „českého“ Chebska a na pás podél česko-bavorské hranice u Neu-Albenreuthu. Z území dnešního Německa berni odváděla ještě tržní ves Marktredwitz, Schirnding ve Smrčinách a některé usedlosti ze vsí v jejich okolí (Klír a kol. 2016, 124-133).

Od roku 1424 v rejstrrících nalézáme u každé lokality sloupec se jmény poplatníků, sloupec $\mathrm{s}$ výší předepsané berně a sloupec $\mathrm{s}$ poznámkou o způsobu jejího zaplacení v daném roce. Pokud poplatník berni v plné výši nezaplatil, písaři často zmínili prŕččinu. V některých letech byla berně poplatníkům prominuta nebo snížena, obvykle kvůli hospodářským potížím nebo vážným škodám na majetku. V rejstř́ících vystupují rovněž usedlosti bez předepsané berně nebo přímo označené jako pusté. Interpretace těchto údajů ale nemůže být přímočará. Zaprvé, zápisy se neřídily pevnými pravidly, neosazená usedlost mohla v různých letech vystupovat tu jako pustá, tu bez předepsané berně a jindy zase jako neplatící. Zadruhé, silný vliv na platební morálku měla vrchnost poddaných, a neplatící usedlost tak mohla být ve skutečnosti osazena a hospodářsky prosperující. Hromadný výskyt neplatičů někdy skutečně souvisel se spory mezi městskou radou a vrchností poddaných, nikoliv s pustnutím a sociálními úhory. Zatřetí, v určitých případech mohl být poplatník zdaněn v rámci městské, nikoliv zemské berně (Klír a kol. 2016, 125-127, 136-144, 162-163).

Do roku 1438 se berní rejstř́íky dochovaly mezerovitě, od kancelářské reformy roku 1441 již souvisle (přehled do roku 1498/1500 srov. Klír a kol. 2016, prŕloha 3). Jejich výpovědí o soudobém válečném plenění se zabýval již W. Heisinger (1938, 295-321), na jehož pionýrskou studii můžeme navázat. $Z$ naší analýzy vyloučíme lokality ležící u Marktredwitz, nebot' z nich byla berně obvykle vybírána sumárně. Navíc na ně doléhala moc braniborských kurfiřtů, takže kolísání ve výběru berně nedokážeme s potřebnou jistotou interpretovat (tab. 4). Stranou ponecháme i další lokality platící obvykle jen sumárně (Starý Hrozňatov/Alt-Kinsberg, Skalná/

\begin{tabular}{|l|l|}
\hline Charakteristika & Lokality \\
\hline Lokality u Marktredwitz & $\begin{array}{l}\text { Marktredwitz, Bergnersreuth, Lorenzenreuth, Pfaffenreuth, Reutlas, Thölau, Klein-Wen- } \\
\text { dern, Seußen }\end{array}$ \\
\hline Sumárně platící lokality & Starý Hrozňatov/Alt-Kinsberg, Skalná/Wildstein, Hazlov/Haslau \\
\hline Jiné & Gosel/Kozly, Querenbach \\
\hline Celkem & $\mathbf{1 3 ~ l o k a l i t ~}$ \\
\hline
\end{tabular}

Tab. 4. Lokality odvádějící alespoň zčásti chebskou zemskou berni v letech 1424-1469, které nebyly zahrnuty do námi posuzovaného souboru.

Tab. 4. Orte, die in den Jahren 1424-1469 zumindest einen Teil der Egerer Landsteuer entrichtet haben und in die von uns beurteilte Gruppe nicht aufgenommen wurden. 
Wildstein, Hazlov/Haslau). V posuzovaném souboru ponecháváme majetkově a mocensky poměrně stabilizované lokality, i když z nich zemskou berni odváděla jen část usedlostí (srov. Klír a kol. 2016, tab. 14).

Námi posuzovaný soubor zahrnul 36 berních rejstříků (1424-1469) a 112 lokalit, v každém roce s 819-956 poplatníky (přibližně 32000 údajů; pro rok 1441 jen 519 údajů; tab. 5). Zvláštní pozornost jsme soustředili na všechny informace o pohromách, jež vedly k úplnému nebo částečnému prominutí zemské berně. Dále jsme evidovali zcela či částečně neplatící poplatníky a poplatníky bez předepsané berně. Konečně jsme si všímali usedlostí označených jako pusté (tab. 6-8). Vzhledem k vysokému množství dat jsme všechny charakteristiky evidovali pouze v rejstř́ících do roku 1452 (graf 2), v dalších jsme se omezili na sledování odpuštěné berně (graf 3; požáry, jiné škody, nespecifikovaný důvod). Můžeme předem zmínit, že v 15. století žádná z posuzovaných lokalit nezpustla a s výjimkou samoty Thiemreuth přetrvaly až do 20 . století.

\begin{tabular}{|c|c|c|c|c|c|c|c|c|c|c|c|}
\hline Rok & 1424 & 1429 & $1432-1434$ & 1438 & 1441 & $1442-1445$ & $1446-1450$ & $1451-1455$ & $1456-1460$ & $1461-1465$ & $1466-1470$ \\
\hline
\end{tabular}

Tab. 5. Počet sledovaných poplatníků (zjednodušeno). K vývoji v rámci celého 15. století srov. Heisinger 1938 , Tabelle 4. Tab. 5. Anzahl der beobachteten Abgabepflichtigen (vereinfacht). Zur Entwicklung im Rahmen des gesamten 15. Jahrhunderts vgl. Heisinger 1938, Tabelle 4.

\begin{tabular}{|l|c|l|}
\hline \multirow{2}{*}{ Pohromy } & 1 & Shoření nebo vypálení usedlosti \\
\cline { 2 - 3 } & 2 & $\begin{array}{l}\text { Jiné škody - odvlečení hospodáře, odvlečení nebo ztráta koní a dobytka, vyplenění } \\
\text { usedlosti a ztráta jejího vybavení, neúroda způsobená výkyvem počasí }\end{array}$ \\
\cline { 2 - 4 } & 3 & Nespecifikované škody \\
\hline $\begin{array}{l}\text { Potenciální sociální úhor } \\
\text { nebo hospodářské potíže }\end{array}$ & 4 & Neplatící poplatník \\
\cline { 2 - 3 } & 5 & Poplatník bez předepsané částky \\
\hline Sociální úhor & 6 & Pustá usedlost \\
\hline
\end{tabular}

Tab. 6. Důvody pro úplné či částečné odpuštění zemské berně v rejstř́cích z let 1424-1452 (1-6) a 1453-1469 (1-3). Tab. 6. Gründe für eine völlige oder teilweise erlassene Landsteuer in den Steuerbüchern der Jahre 1424-1452 (1-6) und 1453-1469 (1-3).

\begin{tabular}{|c|c|c|c|c|c|c|c|c|c|c|c|c|c|c|c|c|c|c|}
\hline & $\stackrel{\stackrel{\Xi}{ \pm}}{\Xi}$ & ปิ & $\stackrel{\widetilde{J}}{\Xi}$ & $\tilde{\tilde{z}}$ & 志 & $\begin{array}{l}\infty \\
\stackrel{\sim}{\Xi}\end{array}$ & $\exists$ & $\stackrel{\text { I }}{\Xi}$ & $\stackrel{g}{I}$ & $\underset{\Xi}{\Xi}$ & $\underset{I}{ \pm}$ & $\stackrel{゚}{ \pm}$ & $\underset{J}{ \pm}$ & $\stackrel{\infty}{ \pm}$ & $\stackrel{g}{I}$ & $\underset{8}{\stackrel{10}{\Xi}}$ & $\underset{\Xi}{ \pm}$ & $\stackrel{\text { ஸี }}{ \pm}$ \\
\hline Požár & 1 & 8 & 22 & 0 & 0 & 0 & 21 & 9 & 0 & 2 & 5 & 3 & 0 & 0 & 0 & 3 & 6 & 172 \\
\hline Škody & 0 & 73 & 1 & 0 & 0 & 1 & 3 & 2 & 0 & 0 & 0 & 0 & 1 & 3 & 0 & 16 & 0 & 1 \\
\hline Nespecifikováno & 2 & 3 & 17 & 3 & 0 & 0 & 1 & 4 & 5 & 2 & 13 & 0 & 0 & 1 & 2 & 0 & 0 & 2 \\
\hline Nezaplaceno & 17 & 1 & 27 & 59 & 39 & 11 & 9 & 8 & 51 & 3 & 9 & 7 & 5 & 8 & 9 & 4 & 10 & 6 \\
\hline Nepředepsáno & 5 & 1 & 1 & 7 & 0 & 19 & 2 & 6 & 11 & 36 & 5 & 3 & 7 & 3 & 2 & 1 & 3 & 6 \\
\hline Pusté & 14 & 7 & 5 & 1 & 2 & 4 & 8 & 30 & 9 & 8 & 11 & 6 & 7 & 3 & 5 & 2 & 4 & 6 \\
\hline $\begin{array}{l}\text { Počet všech } \\
\text { poplatníků } \\
\text { v rejstř́iku }\end{array}$ & 819 & 956 & 956 & 950 & 950 & 901 & 519 & 901 & 891 & 891 & 891 & 891 & 891 & 894 & 894 & 894 & 894 & 894 \\
\hline
\end{tabular}

Tab. 7. Zcela nezaplacená chebská zemská berně v rejstř́cích z let 1424-1452. Absolutní hodnoty. Požár, škody a nespecifikováno - berně byla poplatníkům odpuštěna. Nezaplaceno a nepředepsáno - důvod neuveden. Pusté - neosazená usedlost. Podle př́islušných berních rejstříků.

Tab. 7. Völlig unbeglichene Egerer Landsteuer in den Steuerbüchern der Jahre 1424-1452. Absolute Werte. Brand, Schäden und nicht spezifiziert - die Steuer wurde den Abgabepflichtigen erlassen. Unbeglichen und nicht vorgeschrieben - ohne Angabe des Grundes. Wüstes - nicht besiedeltes Anwesen. Gemäß den einschlägigen Steuerbüchern. 


\begin{tabular}{|c|c|c|c|c|c|c|c|c|c|c|c|c|c|c|c|c|c|c|}
\hline & 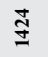 & ఫิ & $\tilde{\overbrace{}}$ & $\stackrel{\widetilde{3}}{\Xi}$ & $\begin{array}{l}\stackrel{ \pm}{\Xi} \\
\end{array}$ & $\stackrel{\infty}{\stackrel{\oplus}{\Xi}}$ & 卞 & $\underset{I}{ \pm}$ & $\underset{I}{I}$ & 导 & $\stackrel{f}{\mathbf{I}}$ & $\stackrel{゚}{ \pm}$ & I & $\stackrel{\infty}{J}$ & $\underset{J}{\exists}$ & $\stackrel{\text { in }}{9}$ & $\overline{\mathbf{n}}$ & $\stackrel{\text { \% }}{ \pm}$ \\
\hline Požár & 1 & 1 & 14 & 2 & 0 & 0 & 0 & 2 & 1 & 0 & 1 & 0 & 0 & 0 & 0 & 0 & 0 & 1 \\
\hline Škody & 1 & 76 & 11 & 3 & 0 & 11 & 0 & 1 & 0 & 0 & 1 & 8 & 13 & 1 & 52 & 0 & 0 & 38 \\
\hline Nespecifikováno & 19 & 20 & 9 & 0 & 1 & 2 & 0 & 17 & 1 & 0 & 2 & 1 & 2 & 2 & 7 & 0 & 0 & 17 \\
\hline Nezaplaceno & 8 & 2 & 5 & 13 & 57 & 92 & 1 & 0 & 0 & 0 & 0 & 0 & 0 & 2 & 3 & 0 & 0 & 0 \\
\hline Nepředepsáno & 0 & 0 & 0 & 0 & 0 & 0 & 0 & 0 & 0 & 0 & 0 & 0 & 0 & 0 & 0 & 0 & 0 & 0 \\
\hline Pusté & 7 & 0 & 0 & 0 & 1 & 0 & 1 & 5 & 6 & 3 & 2 & 1 & 0 & 1 & 0 & 0 & 2 & 1 \\
\hline $\begin{array}{l}\text { Počet všech } \\
\text { poplatníků } \\
\text { v rejstříku }\end{array}$ & 819 & 956 & 956 & 950 & 950 & 901 & 519 & 901 & 891 & 891 & 891 & 891 & 891 & 894 & 894 & 894 & 894 & 894 \\
\hline
\end{tabular}

Tab. 8. Jen částečně zaplacená chebská zemská berně v rejstřících z let 1424-1452. Absolutní hodnoty. Požár, škody a nespecifikováno - berně byla poplatníkům odpuštěna. Nezaplaceno a nepředepsáno - důvod neuveden. Pusté - neosazená usedlost. Podle příslušných berních rejstř́íkủ.

Tab. 8. Nur teilweise entrichtete Egerer Landsteuer in den Steuerbüchern der Jahre 1424-1452. Absolute Werte. Brand, Schäden und nicht spezifiziert - die Steuer wurde den Abgabepflichtigen erlassen. Unbeglichen und nicht vorgeschrieben ohne Angabe des Grundes. Wüstes - nicht besiedeltes Anwesen. Gemäß den einschlägigen Steuerbüchern.

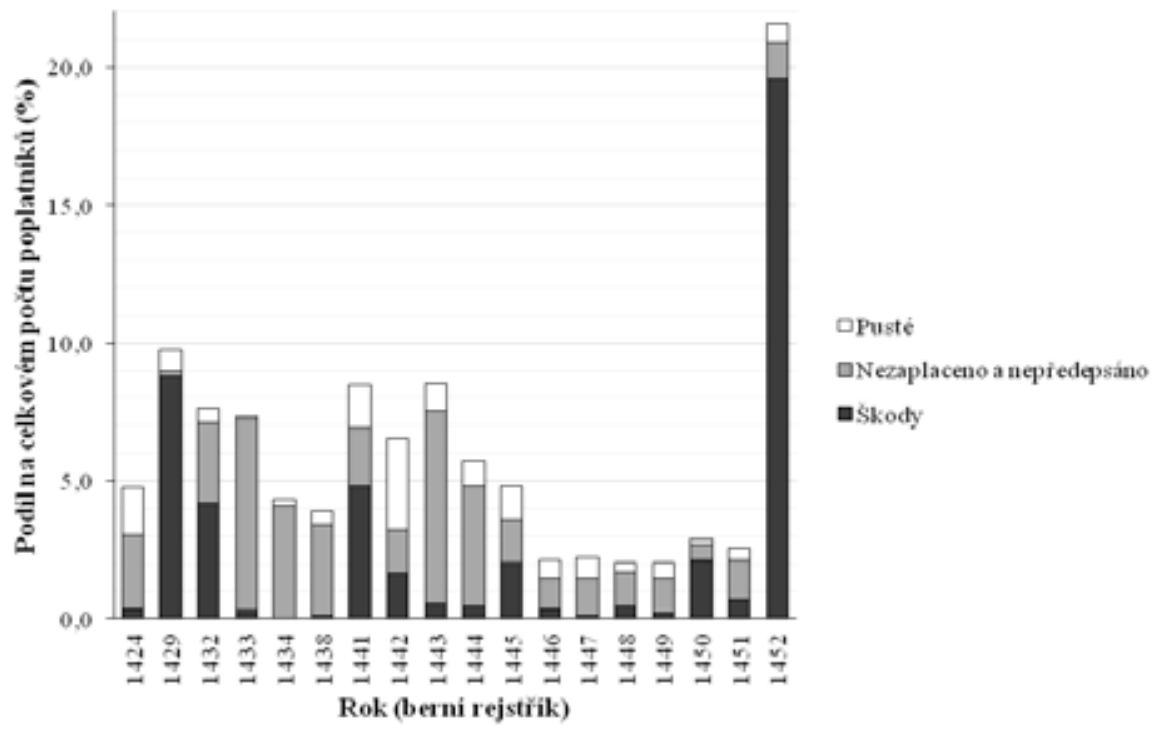

Graf 2. Zcela nezaplacená chebské zemské berně v rejstřících z let 1424-1452. Relativní hodnoty. Škody - berně odpuštěna (požár, škody a nespecifikováno). Podle příslušných berních rejstř́ík.

Diagramm 2. Völlig unbeglichene Egerer Landsteuer in den Steuerbüchern der Jahre 1424-1452. Relative Werte. Schäden erlassene Steuern (Brand, Schäden und nicht spezifiziert). Laut den einschlägigen Steuerbüchern.

\subsection{Di̊sledky válek v 15. století}

\section{Husitské obdobi}

Podle soudobých kronik měla mít na chebský venkov největší dopad tažení a průchody husitských vojsk v červnu 1428, v červenci a říjnu 1429 a v únoru 1430 (Gradl 1893, 367-381; Schlesinger 1974; Heisinger 1938, 295-296; Klír a kol. 2016, 164-165). V tomto ohledu přináší detailní informace berní rejstř́ik z roku 1429 a jeho čistopis. Do přímé souvislosti s válečným pleněním lze dát velké množství neplatících, či jen částečně platících usedlostí v šesti vsích 


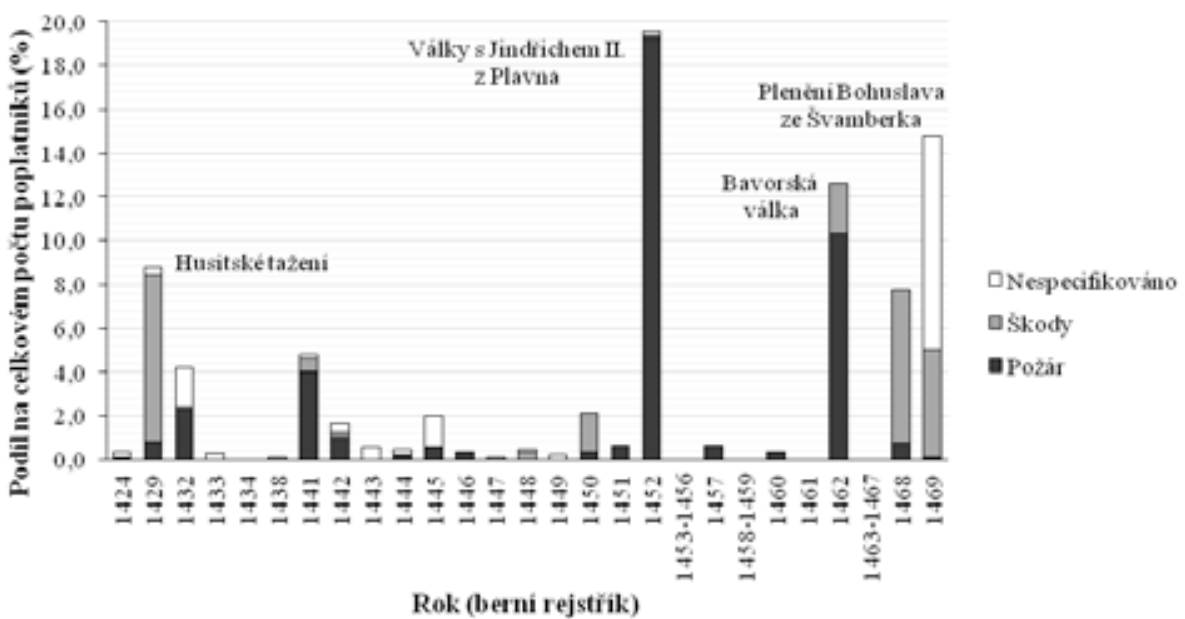

Graf 3. Důvody vedoucí k odpuštění chebské zemské berně v letech 1424-1469. Podle př́íslušných berních rejstříků. Diagramm 3. Gründe, die in den Jahren 1424-1469 zum Erlass der Egerer Landsteuer führten. Laut den einschlägigen Steuerbüchern.

a neplatící jednotlivce $\mathrm{v}$ dalších dvou vsích. Všechny vypleněné vsi ležely pod Žandovským průsmykem nebo v blízkosti cesty, která k němu z Chebu směřovala (obr. 4). Pokud lze určit, $\mathrm{v}$ jedné vsi bylo důvodem pro odpuštění berně odvlečení sedláků a vypálení usedlostí, v jiné uloupení dobytka, ve dvou opět vypálení usedlostí. Paradoxně přibližně stejný výpadek zemské berně jako válečné pustošení způsobila neúroda daná výkyvem počasí v podhưří Smrčin, nebot' $\mathrm{z}$ tohoto důvodu byla polovice berně odpuštěna jedenácti vsím.

Berní rejstřík z roku 1432 eviduje $\mathrm{z}$ vnějšího pohledu poměrně klidnou situaci. Události z roku 1429 se již v rejstříku výrazněji neprojevují, berně byla z toho důvodu odpuštěna jen v jedné vsi. Jako zcela vypálené se však nově uvádí usedlosti ve dvou jiných vsích; různě vysoký počet vyhořelých usedlostí lze dále najít ve dvou vsích postižených husitským pleněním roku 1429 a ve dvou vsích v oblasti neúrody téhož roku. Poměrně zanedbatelný počet shořelých usedlostí rejstřík evidoval ve třech dalších vsích. Na druhé straně jen část chebských vsí odvedla toho roku berni bezproblémově a v plné výši, ve většině vsí bylo alespoň některým usedlostem zčásti, či úplně z berně sleveno, popř́ípadě zůstaly berni dlužny. Konkrétní příčina není obvykle uvedena, a zdá se proto, že výpadek zemské berně souvisel s celkově špatnou hospodářskou bilancí a s př́liš velkým berním zatížením venkova.

Roku 1433 byla výše berně většině vsí plošně snížena, což alespoň zčásti vysvětluje, proč množství neplatících usedlostí kleslo. V některých vsích byla berně odpuštěna z různých důvodů jednotlivým usedlostem, několikrát i kvůli vyhoření, které lze ve větší míře doložit pouze v jedné vsi - Dolních Lomanech / Unter Lohma. Následující léta 1434-1435 lze hůře posoudit, nebot' berní rejstř́iky se dochovaly v různě velkém torzu. V zápisech nelze sledovat žádnou výraznější katastrofu, berni neplatily pouze jednotlivé usedlosti. V Dolních Lomanech se důsledky požáru $\mathrm{z}$ minulého roku u většiny postižených usedlostí již ani neprojevily.

\section{Válka s Jindřichem II. z Plavna}

V berních rejstřících ze 40 . letech 15 . století se lze v mnoha vsích setkat s jednotlivě vyhořelými usedlostmi, s usedlostmi obranými o dobytek, s neosazenými či pustými usedlostmi a s tím souvisejícím výpadkem berně (srov. také Heisinger 1938, 305-307; Klír a kol. 2016, 165). Pokud jde o rozsáhlejší škody, roku 1441 vyhořela celá ves Dřenice/Treunitz, jež o rok později 


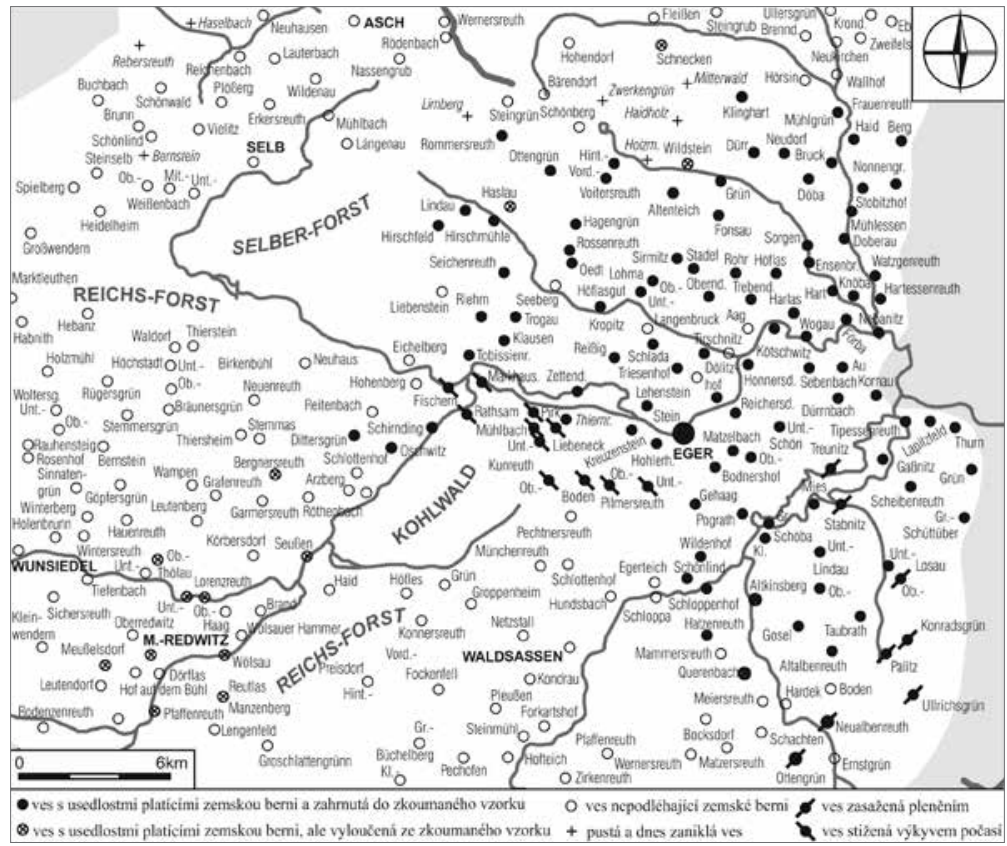

Obr. 4. Vsi zasažené pohromami v roce 1429. Husitská tažení a neúroda způsobená výkyvy počasí. Oblast mimo tzv. historické Chebsko nesledována.

Abb. 4. Von Pogromen im Jahr 1429 heimgesuchte Dörfer. Hussitenfeldzüge und von Wetterschwankungen verursachte Missernten. Das Gebiet außerhalb des sog. historischen Egerlandes blieb unberücksichtigt.

platila jen poloviční berni, v následujících letech pak opět běžnou. Roku 1451 vyhořela část vsi Táborská/Seuchenreuth.

Skutečně rozsáhlý zásah přinesl konflikt mezi Chebem a míšeňským purkrabím Jindřichem II. z Plavna v letech 1452-1453 (Gradl 1881; Knoll 2008, 187-188). Zvláštní stránka na konci berního rejstř́ku z roku 1452 uvádí šestnáct zcela a osm z velké části vypálených vsí (Klír a kol. 2016, příloha 15). Detailnější pohled do rejstř́iků ukázal zajímavé detaily. Ve vsi Chocovice/Kötschwitz zůstal ušetřen pouze mlýn, v nedalekém Vokově/Wogau to byl naopak právě jen mlynář, jenž vyhořel. Všechny postižené vsi se nalézaly ve východní části Chebska, které během války nejvíce trpělo pleněním vojsk Jindřicha z Plavna a jeho českých i vogtlandských spojenců (obr. 5). Přes velké škody však všechny vypálené vsi již o rok později odváděly poloviční berni a roku 1454 opět plnou. V letech 1455-1456 chebský venkov žádná výrazná pohroma nezasáhla, následujícího roku vyhořela $\mathrm{z}$ velké části ves Třebeň/Trebendorf a roku $1460 \mathrm{Neu}$-Albenreuth (srov. Heisinger 1938, 308-309).

\section{Bavorská válka 1459-1463}

Širší historické pozadí mělo plenění chebských vsí českým vojskem roku 1462 během tzv. bavorské/knížecí války. Na počátku válečného konfliktu stály snahy hohenzollernského markrabího Albrechta III. Achilla, držitele franckého Ansbašska, o posílení vlastní jurisdikční a teritoriální moci v rámci říše. To vedlo ke střetu s witelsbašským vévodou Ludvíkem IX. Bohatým. Do konfliktu se zapojila další ŕíšská knížata a jako zprostředkovatel rovněž Jiří z Poděbrad, jenž zaštítil mírová jednání, probíhající roku 1461 mj. na říšském sněmu v Chebu. Konflikt nakonec 


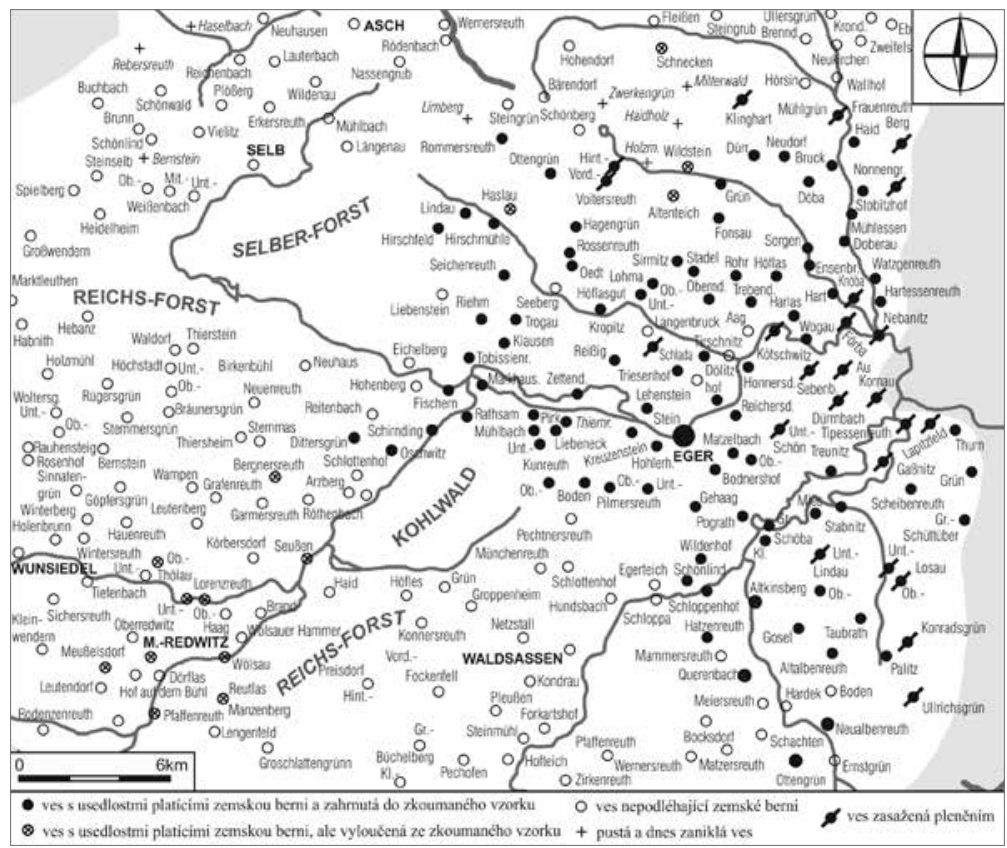

Obr. 5. Vsi zasažené válkou s Jindřichem II. z Plavna roku 1452. Oblast mimo tzv. historické Chebsko nesledována.

Abb. 5. Vom Krieg gegen Heinrich II. von Plauen im Jahr 1452 in Mitleidenschaft gezogene Dörfer. Das Gebiet außerhalb des sog. historischen Egerlandes blieb unberücksichtigt.

ukončil až tzv. pražský mír roku 1463 (např. Weiß 2007; Lackner 2011, 191-235; Seyboth 2014; Siegl 1904).

V průběhu vrcholících válečných akcí v roce 1462 se král Jiří spolu s Chebem přiklonili na stranu vévody Ludvíka a české vojsko bylo vysláno do Horních Frank, do oblasti hohenzollernské oblasti Sechsämter, kde se soustředilo na obléhání klíčového města Wunsiedel. Vojsko se nakonec bez úspěchu stáhlo v důsledku neklidné situace v Čechách a také kvůli sporu s Chebem. S návratem do Čech je pak spojováno rozsáhlé plenění zmiňované rovněž chebskými městskými kronikami (Bartl 2003; Stadelmann 1862).

Podle berního rejstříku z roku 1462 zcela vyhořelo nebo bylo vyvráceno devět vsí. Škody utrpělo několik usedlostí v sedmi vsích. Zasažené vsi vytvárí nepřerušený pás táhnoucí se podél Reslavy a Ohře, což dobře odpovídá soustavnému pustošení českého vojska stahujícího se podél hlavní komunikační tepny z oblasti Sechsämter ve Smrčinách přes Chebskou pánev do Čech (obr. 6). Plenění si nevyžádalo žádné zjistitelné oběti, jména poplatníků ve vsích se nezměnila. Poničené vsi a usedlosti získaly v následujícím roce jako obvykle poloviční úlevu v placení berně a roku 1464 ji odváděly opět celou (srov. Heisinger 1938, 310-312).

\section{Válka s Bohuslavem ze Švamberka 1468-1469/1470}

Roku 1466 byl český král a zástavní držitel Chebska Jiř́ z Poděbrad stižen papežskou klatbou, čímž se politická pozice Chebu dramaticky vyostřila. Praktická neutralita města a věrnost českému králi vedla k vyhlášení prvního interdiktu na přelomu let 1467 a 1468. Po olomoucké volbě českým králem Matyáš Korvín ustanovil Bohuslava ze Švamberka, předního západočeského šlechtice a představitele Zelenohorské jednoty, nejvyšším hofmistrem a chebským 


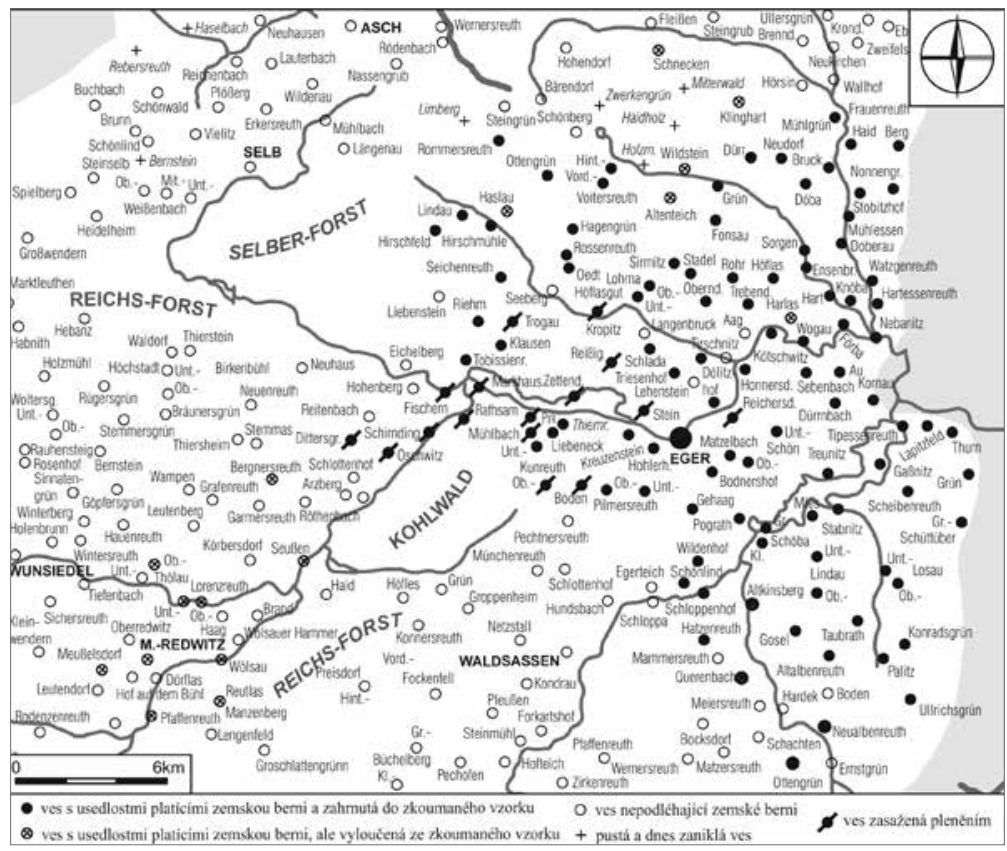

Obr. 6. Vsi vypleněné českým vojskem během tzv. bavorské/knížecí války roku 1462. Oblast mimo tzv. historické Chebsko nesledována.

Abb. 6. Dörfer, die von der böhmischen Armee während des sog. Bayerischen Krieges/Fürstenkrieges 1462 geplündert wurden. Das Gebiet außerhalb des sog. historischen Egerlandes blieb unberücksichtigt.

hejtmanem (k němu Nohová 2008). Bohuslavovým úkolem bylo přimět všemi prostředky chebskou městskou radu k holdování novému králi. Po neúspěšném diplomatickém jednání nejen Bohuslava ze Švamberka, ale i papežských legátů následovaly sankce, interdikt a rozsáhlé pustošení venkova, které během roku 1470 splnily svůj kýžený cíl (např. Sturm 1960, 110-113; Kubů 2006, 64).

O plenění v letech 1468-1469, za nímž stály vojenské skupiny Bohuslava ze Švamberka a dalších přívrženců Matyáše Korvína, informují berní rejstř́íky velmi detailně. Mimo tradičních poznámek o vypálení a plenění nebo odvlečení hospodáře totiž u některých usedlostí přímo vyčíslují konkrétní ztráty na živém i neživém inventáři (přílohy 1-3). Roku 1468 vyhořelo zcela pět vsí, zčásti lehlo popelem šest vsí, různé další škody utrpěly usedlosti v šesti vsích. K roku 1469 se jako zcela vypálené uvádí další čtyři vsi, kvůli nespecifikovaným škodám byla berně odpuštěna všem usedlostem v deseti vsích a některým ve dvou vsích. Všechny vsi postižené v letech 1468-1469 se nacházely v enklávách napříč celým Chebskem (obr. 7).

Pokud něco odlišovalo válečné pohromy z let 1468-1469 od předchozích, byla to snad jejich opakovanost. Možná i proto se vypleněné vsi a usedlosti dlouho nevzpamatovaly a berni neodváděly až do roku 1477. Po tomto roce ji sice neodváděly také, z toho ale nelze mnoho vyvozovat, nebot' tehdy přestávalo berni odvádět velké množství poplatníků kvůli sporům mezi městem a venkovskou šlechtou. K nápravě došlo teprve po zásahu krále Vladislava roku 1486 (Heisinger 1938, 313-320; Klír a kol. 2016, 39, 163).

Výpadek v placení zemské berně po roce 1470 měl ale hlubší příčiny než jen opakované válečné plenění. Ještě před spory s venkovskou šlechtou roku 1477 totiž berni přestávalo zcela či zčásti odvádět stále více a více vsí a usedlostí. Mimo vsí vypleněných v dvouletí 1468-1469 


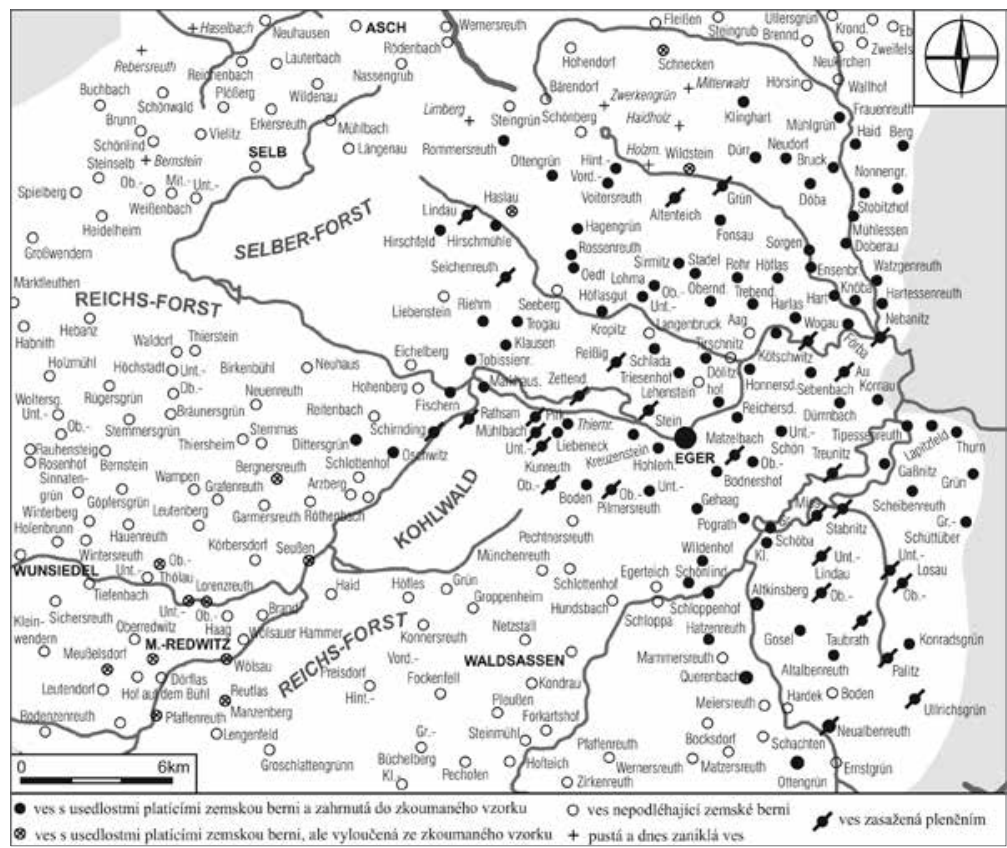

Obr. 7. Vsi vypleněné vojskem Bohuslava ze Švamberka a dalšími nepřáteli Jiřího z Poděbrad a Chebu v letech 1468-1469. Oblast mimo tzv. historické Chebsko nesledována.

Abb. 7. Dörfer, die von der Armee von Bohuslav von Schwanberg und weiteren Feinden von Georg von Podiebrad und Eger in den Jahren 1468-1469 geplündert wurden. Das Gebiet außerhalb des sog. historischen Egerlandes blieb unberücksichtigt.

přestala roku 1470 berně plynout z dalších devíti vsí, roku 1471 se přidalo dalších osm, v letech 1472-1476 tento počet narůstal vždy o tři až osm ročně. Teprve roku 1477 se přidal výše zmíněný výpadek způsobený spory o placení berně s lokální šlechtou (Heisinger 1938, 316-317). Na tomto místě není prostor pro podrobnější analýzu, chebské berní rejstř́íky však mohou přispět k hlubšímu poznání toho, jaké bylo obecné ekonomické pozadí krize a hromadného pustnutí vsí v širším období česko-uherských válek ( $\mathrm{k}$ hospodářské a demografické situaci na nedalekém Norimbersku srov. Bauernfeind 1993, 178-217; k Čechám Maur 2013, 65-66).

\section{Konflikt s Jindřichem II. z Plavna}

Roku 1478 byl chebský venkov znovu zpustošen vojskem a přívrženci míšeňského purkrabího Jindřicha II. z Plavna, jenž zůstával nepřítelem Chebu i českých králů. O důsledcích tohoto plenění, stejně jako ostatních pohrom té doby, nepodávají již berní rejstř́iky jasnou a vyrovnanou zprávu, nebot' berni neodvádělo z různých důvodů př́íliš mnoho poplatníků. W. Heisinger nicméně upozornil na soudobou evidenci města Chebu, v níž jsou vyjmenovány postižené lokality a rozepsány konkrétní škody (Heisinger 1938, 318-320). Rozsáhlý seznam tehdy obsáhl kolem 40 lokalit, některé z nich ale nespadaly pod zemskou berni (tab. 9; obr. 8).

\section{Shrnutí di̊sledků válečného plenění}

Písaři chebského zemského bernictví nebyli důslední, a proto o válečných škodách i jiných pohromách, jež stíhaly venkovské obyvatelstvo, neexistuje vyrovnaná evidence. Svou roli sehrálo i to, že pro období do roku 1441 pracujeme nejen s uzavřenými čistopisy berních rejstříků, ale také s nefinalizovanými exempláři (srov. seznam pramenů; Klír a kol. 2016, 78-81). V principu 


\begin{tabular}{|l|l|l|}
\hline Au/Loužek & Honnersdorf/Jindřichov & Pirk/Bříza \\
Boden (St. Anna) & Knöba/Hněvín & Rathsam \\
Bodnershof & Kötschwitz/Chocovice & Reichersdorf/Hradiště \\
Dölitz/Dolnice & Kreuzenstein/Podhoří & Rohr/Nový Drahov \\
Dürrnbach/Potočiště & Kunreuth, Unter-/Hraničná Dolní & Sebenbach/Chvoječná \\
Ensenbruck/Povodí & Langenbruck/Dlouhé Mosty & Schön, Unter-/Dvory Dolní \\
Fischern & Liebeneck/Tủně & Schönlind/Krásná Lípa \\
Fonsau/Vonšov & Markhausen/Pomezná & Sirmitz/Žírovice \\
Frauenreuth/Kopanina & Mühlbach/Pomezí nad Ohří & Stadel/Stodola \\
Gehaag/Háje & Oberndorf/Horní Ves & Thiemreuth \\
Grün/Zelená & Pilmersreuth, Ober-/Pelhřimov Horní & Triesenhof/Stř́̌žov \\
Hohlerhof & Pilmersreuth, Unter-/Pelhřimov Dolní & \\
\hline
\end{tabular}

Tab. 9. Lokality vypleněné během konfliktu roku 1478. Podle Heisinger 1938, 319.

Tab. 9. Während des Konfliktes im Jahr 1478 geplünderte Orte. Nach Heisinger 1938, 319.

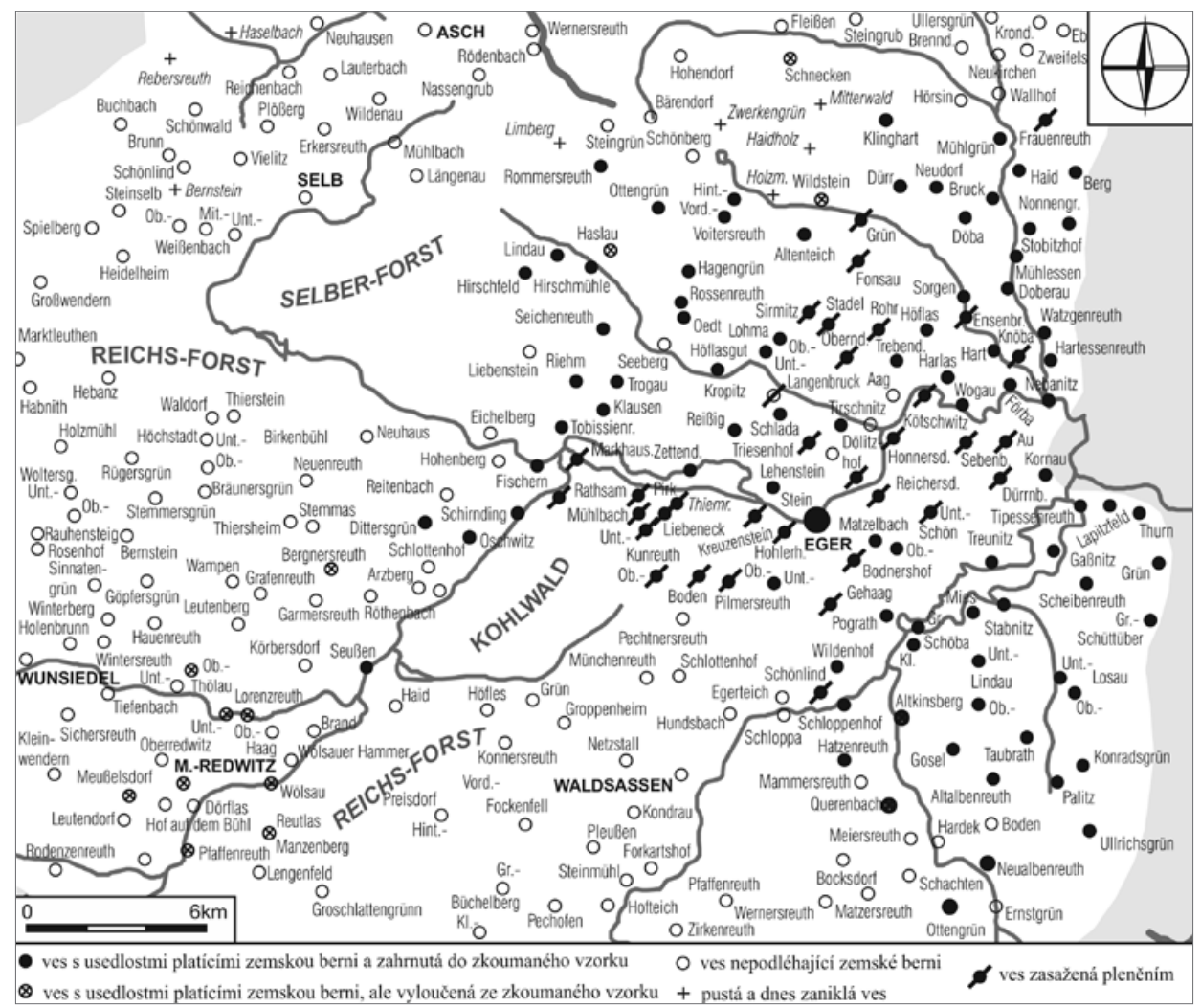

Obr. 8. Vsi vypleněné vojskem Jindřicha II. z Plavna a jeho spojenci roku 1478. Podle zvláštního soupisu města Chebu (tj. oproti berním rejstř́íum nadreprezentováno). Oblast mimo tzv. historické Chebsko nesledována.

Abb. 8. Dörfer, die von der Armee von Heinrich II. von Plauen und seinen Verbündeten im Jahr 1478 geplündert wurden. Laut einem Sonderverzeichnis der Stadt Eger (d.h. gegenüber den Steuerbüchern überrepräsentiert). Das Gebiet außerhalb des sog. historischen Egerlandes blieb unberücksichtigt.

se setkáváme se zápisy o odpuštění berně bud’ bez jakékoliv specifikace, nebo s určením př́ičiny, kterou mohl být požár, ztráta koní a dobytka, popřípadě neživého inventáře usedlosti, odvlečení hospodáře, jen výjimečně jsou zmiňovány př́rodní pohromy. V rámci analýzy můžeme všechny tyto události spojit do jedné skupiny a pro jednoduchost neodlišit škody způsobené př́rodními 


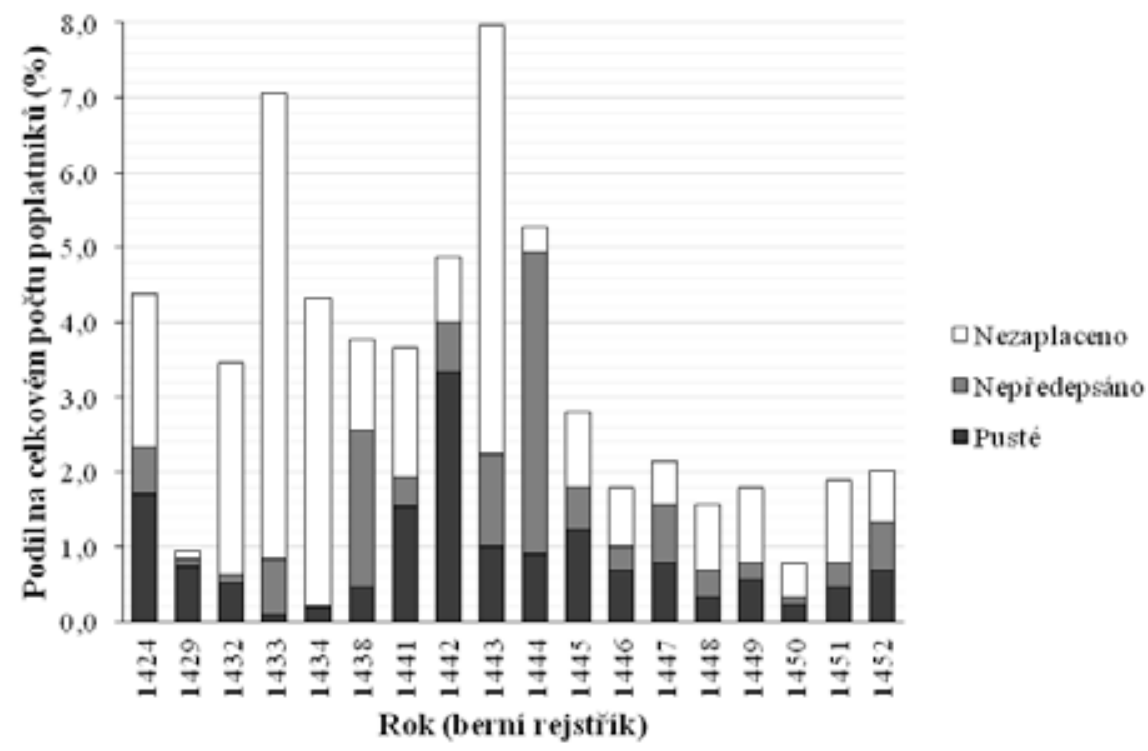

Graf 4. Podíl pustých a neplatících usedlostí na celkovém počtu poplatníků (1424-1452). Poplatníci, jimž byla berně z různých důvodů prominuta, nejsou zahrnuti a pojednává je kap. 5.1. Podle př́íslušných berních rejstř́iků.

Diagramm 4. Anteil der wüsten und nicht zahlenden Anwesen an der Gesamtanzahl der Abgabepflichtigen (1424-1452). Abgabepflichtige, denen man die Steuer aus verschiedenen Gründen erlassen hatte wurden nicht aufgenommen und werden in Kap. 5.1. behandelt. Laut den einschlägigen Steuerbüchern.

faktory, nebot' ty s výjimkou roku 1429 nepřekročily hranici jednotlivin. Zvlášt' je tř̌eba zároveň posuzovat úplné, nebo jen částečné odpuštění berně. Vzhledem ke kolísání počtu poplatníků a vsí v našem vzorku je důležité relativní srovnání (např. rejstř́íky z let 1424 a 1441 se nedochovaly kompletní).

Během sledovaného období postihly chebský venkov čtyři rozsáhlá válečná plenění, a to v letech 1429/1430, 1452, 1462, 1468-1470, tedy v rozmezí 6 až 22 let. Mimo námi sledovaný časový úsek leží ještě škody, které způsobilo plenění roku 1478, jež nelze detailněji sledovat v berních rejstřících, a není tedy s ostatními plně srovnatelné. Mimo hlavní krizové roky byly jednotlivé vsi a usedlosti stíhány dalšími, lokálními pohromami. Nicméně i přes tuto enormní zátěž zasahující tehdy chebský venkov nedošlo nikde k vylidnění, jež by se projevilo v pustnutí usedlostí nebo dokonce zániku vsí. Chebsko tak nesledovalo cestu nedalekých západočeských pahorkatin (z rozsáhlé literatury Maur 2013; dále např. Vařeka a kol. 2006; Rožmberský-Vařeka 2013). To lze alespoň zčásti vysvětlit tím, že v 15. století se dosah chebské zemské berně zúžil především na zemědělsky a sídelně poměrně příznivou Chebskou pánev, vytvářející hospodářské zázemí a subsistenční základnu nejen pro Cheb s přibližně 5000 obyvateli, ale také pro přilehlé horské regiony (srov. Klír a kol. 2016, 46-48). Jestliže přesto náznaky pustnutí tehdy někdy nacházíme, pak v pahorkatinách za hranicí Chebské pánve (srov. dále).

$\mathrm{K}$ regeneraci vsí a usedlostí jistě přispívala i skutečnost, že žádná z pohrom si obvykle nevyžádala životy hospodářů. Detailnější berní rejstřík z roku 1468 také př̌esvědčivě dokládá, že alespoň někteří z nich část nejcennějšího vybavení svých usedlostí před pleněním zachránili.

Grafy 2 a 3 ukazují, že škody způsobené pleněním postihly vždy jen část chebského venkova, a to v rozsahu 10-20\% usedlostí. S tím souvisí i nerovnoměrný geografický dopad. Pleněním byly nejčastěji ohrožovány lokality ležící ve větší vzdálenosti od Chebu a také v blízkosti komunikačních tepen, zvláště směrem do Čech. Některé vsi se tak obětí neklidných válečných let nikdy nestaly, naopak jiné byly pohromami stíhány opakovaně. 


\subsection{Pusté usedlosti a sociální úhory 1424-1452}

O sociálních úhorech svědčí usedlosti, u nichž si berní písaři poznamenali, že jsou pusté (,leyt wüste“; „,ist öde“). Označení „öde“ ale nebylo normativní, a pokud je písaři neuvedli, nedokážeme pustou usedlost odlišit od poplatníků, kteří berni neodvedli nebo jim nebyla ani předepsána (případy, kdy berně byla prominuta, shrnuje předchozí kap. 5.1). Mimo explicitní zmínky o poustkách proto musíme vzít v úvahu i ostatní, zdánlivě bezdůvodně neplatící usedlosti. Vzhledem k vysokému množství dat se omezíme pouze na 18 berních rejstř́ků z rozmezí let 1424-1452, což i tak znamená analýzu kolem 15000 údajů (graf 4).

Ze 112 posuzovaných lokalit byly pusté usedlosti zmíněny v polovině, tedy v 55 lokalitách (př́loha 4). $Z$ toho pro 25 lokalit je k dispozici pouze jediný doklad. Ani ve zbývající 30 lokalitách pusté usedlosti obvykle nepředstavovaly hromadný a opakující se jev. Trvaleji prrítomné pustiny lze doložit pouze $\mathrm{v}$ devíti vsích, a to často $\mathrm{v}$ těch $\mathrm{s}$ větším množstvím poplatníků, takže jejich relativní podíl nebyl př́liš vysoký (Salajna/Konradsgrün, Horní Lomany/Ober-Lohma, Poustka/Oed, Palič/Palitz, Rathsam, Oldřichov/Ulrichsgrün). V celé naší evidenci tak zbývají jen dvě vsi ohrožené ve větší míře sociálními úhory a směřující kolem poloviny 15 . století k vylidnění - Dolní Lipina/Unter-Lindau a Dolní Lažany/Unter-Losau. Není náhodné, že podstatná část vsí s větším množstvím pustých usedlostí ležela $v$ jedné z mála hornatých enkláv, do kterých ještě chebská zemská berně po roce 1424 dosáhla - na úpatí Hornofalckého/Českého lesa.

Značné kolísání v záznamech pustých usedlostí v jednotlivých berních rejstřících lze do velké míry vysvětlit nesoustavností písařů. Nápadně vysoký je počet pustých usedlostí v rejstřících za roky 1424, 1441 a 1442 . V jiných rejstř́ících nemusely být pusté usedlosti systematicky označovány a mohou se hojněji skrývat $\mathrm{v}$ nespecifikované kategorii neplatících usedlostí. Písařská praxe byla nejspíše taková, že krátkodobě neosazené usedlosti jako pusté vedeny ani nebyly. Výmluvné jsou v tomto ohledu poznámky, že usedlost byla právě osazena novým hospodářem, a proto berni ještě neplatila (tab. 10:A). Nebo se hospodář vystěhoval či zemřel, a proto se z usedlosti neplatilo (B). Pustá usedlost v berních rejstřících tedy znamená spíše dlouhodobě nepřekonaný sociální úhor, popřípadě již jen dvořiště ve vsi (explicitně C). Ke slučování usedlostí samozřejmě docházelo, aniž by jedna z nich musela být pustá (D). Podobně docházelo i k jejich dělení (srov. Klír a kol. 2016, 134-135).

Nízký počet současně pustých usedlostí a jejich krátkodobost nepřekvapuje, nebot' ve vsi nepředstavovaly stabilní prvek. Mnoho z nich, at' se jednalo o chalupy, nebo větší dvory, byly postupně pohlcovány jinými usedlostmi, které za ně začaly odvádět berni. Pustá usedlost byla tímto způsobem často rychle integrována do jiné, které berní úředníci navýšili sazbu. Pustá usedlost následně vypadla $z$ písemné evidence (E). Jednou je dokonce zmíněno, že dvůr pusté usedlosti byl stržen (F). Několikrát lze doložit, že dlouhodobě pustá usedlost byla znovu osazena $(\mathrm{G})$.

\begin{tabular}{|c|l|}
\hline A & Nebanice/Nebanitz 1424 - kovář, Horní Hraničná/Ober-Kunreuth 1445 \\
\hline B & $\begin{array}{l}\text { Obilná/Kornau 1424, Mühlessen/Milhostov 1424 - kovář, Podhrad/Pograt 1429, Horní Ves/Oberndorf 1449, } \\
\text { Dolní Pelhřimov/Unter-Pilmersreuth 1443 a 1444, Stebnice/Stabnitz } 1449\end{array}$ \\
\hline C & Markhausen/Pomezná, Dolní Dvory/Unter-Schön 1424, Dřenice/Treunitz 1442 \\
\hline D & Dietersgrün 1446, Chocovice/Kötschwitz 1446, Podhrad/Pograt 1446, Chvoječná/Sebenbach 1447 \\
\hline E & $\begin{array}{l}\text { Dolní Lomany/Unter-Lohma 1424, Doubrava/Doberau 1444, Dolní Lipina/Unter-Lindau, } 4 \text { usedlosti 1444, Nový } \\
\text { Drahov/Rohr 1448 }\end{array}$ \\
\hline F & Stebnice/Stabnitz 1424 \\
\hline G & Lesina/Hart 1442, Slatina/Schlada 1445, Chvoječná/Sebenbach 1443 \\
\hline
\end{tabular}

Tab. 10. Vsi umožňující konkrétnější poznání sociálních úhorů.

Tab. 10. Dörfer, die konkretere Erkenntnisse über Sozialbrachen möglich machen. 


\section{Závěr}

Předkládaná studie měla za cíl konkretizovat naše poznatky o 1) procesu pustnutí venkovských sídlišt' v 90. letech 14. století, 2) průběhu a dopadu lokálních konfliktů v 15. století a 3) sociálních úhorech. Pro detailní analýzu jsme vybrali Chebsko, a to s ohledem na unikátní pramennou evidenci v podobě rejstříků chebské zemské berně (1392-1757). Ty dovolují sledovat sociálně-ekonomický vývoj více než stovky vsí zprvu mezerovitě, od roku 1441 již kontinuitně, a to na úrovni jednotlivých usedlostí doslova rok po roce.

Výpověd' berních rejstříků nelze samozřejmě ani přeceňovat, ani př́ímočaře interpretovat. Přes jistou dávku skepse je ale i tak patrné, že nejstarší dochované rejstř́íky z let 1392-1409 odráží dvě kvalitativně i chronologicky odlišné roviny a zároveň skupiny pustých vsí. Zaprvé vsi již nějaký čas prakticky pusté, s dlouhodobě přetrvávajícími sociálními úhory, o jejichž osazení nebyl přinejmenším od 80 . let 14. století zájem. Tyto vsi zpravidla definitivně zanikly (kap. 4.1). Zadruhé vsi, které se sice právě propadaly na své populační dno, ale jednalo se jen o aktuální krátkodobý výkyv, který mohl být záhy překonán (kap. 4.2). Vysoké množství dlouhodobě i krátkodobě pustých vsí uváděných v berním rejstříku z roku 1397 přitom pravděpodobně odráží předcházející morovou vlnu (1395), indikovanou i rejstř́iky chebské městské berně (kap. 4.3).

Pustnutí chebských vsí v pozdním středověku vnímáme jako důsledek rozpadu a zániku rolnických komunit na pozadí vysoké úmrtnosti a depopulace. Sociální úhory byly rychle překonány ve vsích s relativně př́iznivými sídelními podmínkami, v ostatních mohlo dojít k rozsáhlému pustnutí. Po vymření jádra rolnické komunity, jejíž členové měli silné vazby na místo jinak relativně nevábné, zbytek odcházel, setrvávali spíše starci nebo vdovy (Plößberg u Selbu). Přikláníme se tak k těm proudům, jež v procesu pustnutí dávají úlohu prvotního hybatele demografickému vývoji a ostatní faktory považují za sekundární. Tím ale jejich význam nesnižujeme, nebot' právě faktory jako př́rodní dispozice, odbytové možnosti, vnitřní soudržnost rolnické komunity, zájmy vrchnosti nebo sousedních rolnických komunit do velké míry určovaly, zda bude pustnutí překonáno a ves znovu osazena, nebo bude osídlení nově strukturováno a ves zanikne.

Vsi evidované v berních rejstřících v 20.-60. letech 15 . století vykazovaly neobyčejnou vitalitu, hospodářské i demografické rezervy, a s tím i regenerační potenciál (kap. 5.1). V důsledku nehod nebo válečných událostí lehlo požárem opakovaně mnoho usedlostí i celých vsí, poddaní přicházeli o dobytek, koně, úrodu a neživý inventář, přesto své usedlosti vždy rychle obnovili a škody - alespoň z pohledu berní potence - do roka až dvou plně překonali. Ke zlomu došlo v 70. letech 15. století, které lze charakterizovat jako období obecného berního výpadku, jež by bylo třeba hlouběji analyzovat.

Neosazené a pusté usedlosti byly běžným, i když nikoliv hromadným jevem, který lze spojit s krátkodobými hospodářskými výkyvy a demografickými cykly (kap. 5.2). Pusté usedlosti, doložené v celé polovině posuzovaných vsí, znamenaly dlouhodobě nepřekonané sociální úhory, a tím i demografické nebo hospodářské potíže rolnické komunity. Nic na tom nemění nízký počet pustin, nebot' analyzováno bylo jen 18 berních rejstř́íků, tj. pouze 18 let.

Pusté usedlosti představovaly dynamický prvek, umožňující nejen korekce půdorysné osnovy vsi, ale také adaptaci rolnické komunity. Jestliže promítneme zjištěný výskyt a četnost pustých usedlostí do delšího časového úseku, uvědomíme si, jak nesmírně živě mohly některé vesnické intravilány vnitřně pulzovat.

Náš př́ispěvek analyzující písemnosti zemského bernictví se týká jen jednoho středoevropského regionu v pozdním středověku. Pro Čechy a Moravu je metodicky obdobný postup možný teprve od druhé poloviny 17. století, kdy byla vyhotovena berní rula a lánové rejstříky.

Tato studie vznikla v rámci programu Univerzity Karlovy Progres č. Q07 s názvem „Centrum pro studium středověku“.

Pokud není uvedeno jinak, autorem všech obrázků je autor. 


\begin{tabular}{|l|l|c|}
\hline \multicolumn{1}{|c|}{ Poplatník } & \multicolumn{1}{c|}{ Ztráta } & Platba** \\
\hline Hanns Pawer & 6 kusů koní a krav, svršky* & zaplatila \\
\hline Smidel Mülnerin & všechny svršky & 0 \\
\hline Herolt & 6 krav, všechny svršky & 0 \\
\hline Jorg Hans & 6 krav a jalovic & 0 \\
\hline Rudusch & 1 kůn̆, 1 jalovice, 3 kusy dobytka zůstaly & 0 \\
\hline Hanns Trag & 3 krávy, 1 jalovice, svršky & 0 \\
\hline Trapp & 6 krav a svršky & zaplatil \\
\hline Hanns Smidel & všechny svršky & 0 \\
\hline Erhart von Pruck $<$ Michel> & 3 krávy, 1 jalovice, svršky & 0 \\
\hline Heynz Gotz & všechny svršky & pusté \\
\hline Vlrich Eck & 2 krávy, všechny svršky & 0 \\
\hline Hans Padin & - & 0 \\
\hline Hanns Fridel & všechen dobytek a svršky & 0 \\
\hline Smid Mulne[rs] eydem & 2 krávy & \\
\hline
\end{tabular}

Př́íloha 1. Výsledek plenění roku 1468 ve vsi Pomezí nad Ohří/Mühlbach. Podle berního rejstříku z roku 1468, nefol. * - svršky (,plunder“) - kompletní neživý inventář usedlosti (srov. Grimm DWB, Bd. 13, Sp. 1945-1947); ** - roku 1469 berně neplacena.

Anhang 1. Resultat der Plünderung von 1468 im Dorf Pomezí nad Ohř́i/Mühlbach. Laut dem Steuerbuch aus dem Jahr 1468, unfol. * - Plunder - komplettes totes Inventar des Anwesens (vgl. Grimm DWB, Bd. 13, Sp. 1945-1947); ** - im Jahr 1469 nicht entrichtete Steuer.

\begin{tabular}{|l|l|c|}
\hline \multicolumn{1}{|c|}{ Poplatník } & \multicolumn{1}{c|}{ Ztráta } & Platba* \\
\hline Heckel & 8 krav & zaplatil \\
\hline Fischer & 1 kráva & zčásti zaplatil \\
\hline Walhawser & všechen dobytek a koně & zaplatil \\
\hline Czolichn[er] & vojenská výzbroj & 0 \\
\hline Winckler & 3 koně & 0 \\
\hline Fluthner & všechen dobytek a koně & zaplatil \\
\hline Freyßleben & vojenská výzbroj a všechny svršky & zaplatil \\
\hline Pecker & uchoval si dobytek & usedlost prodána \\
\hline Mulnerin & beze ztrát & \\
\hline
\end{tabular}

Př́íloha 2. Výsledek plenění roku 1468 ve vsi Skalka/Stein. Několik hospodářů přišlo o výzbroj, se kterou měli sloužit v chebské venkovské hotovosti. Podle berního rejstř́iku z roku 1468, nefol. * - roku 1469 berně neplacena.

Anhang 2. Resultat der Plünderung von 1468 im Dorf Skalka/Stein. Einige Bauern kamen um die Ausrüstung, mit der sie im Egerer Dorfaufgebot dienen sollten. Laut dem Steuerbuch aus dem Jahr 1468, unfol. * - im Jahr 1469 nicht entrichtete Steuer.

\begin{tabular}{|l|l|}
\hline \multicolumn{1}{|c|}{ Poplatník } & \multicolumn{1}{c|}{ Ztráta } \\
\cline { 1 - 2 } Nickel Jacobn son & krávy, koně a svršky \\
\hline Kuncz Gocz & všechen dobytek, hospodář zajat \\
\hline Pewmel & dobytek a koně \\
\hline Nickel Fisch[er] & vše vzato, usedlost vyhořela \\
\hline Hanns Solich & dobytek, koně, svršky \\
\hline Nickel Dobrawer & všechen dobytek, hospodář zajat \\
\hline Peter Fischer & všechen dobytek \\
\hline V̈bel Acker & všechen dobytek \\
\hline Ott & všechen dobytek, hospodář zajat \\
\hline
\end{tabular}

Př́íloha 3. Výsledek plenění roku 1468 ve vsi Bříza/Pirk. Několik hospodářů bylo zajato a odvlečeno. Podle berního rejstř́íku z roku 1468, nefol. * - roku 1469 berně neplacena.

Anhang 3. Resultat der Plünderung von 1468 im Dorf Bř́za/Pirk. Einige Bauern wurden gefangen genommen und verschleppt. Laut dem Steuerbuch aus dem Jahr 1468, unfol. * - im Jahr 1469 nicht entrichtete Steuer. 


\begin{tabular}{|c|c|c|c|c|c|c|c|c|c|c|c|c|c|c|c|c|c|c|}
\hline Název vsi a počet poplatníků & $\underset{\Xi}{\Xi}$ & ఫิ & $\widetilde{\vartheta}$ & $\tilde{\Im}$ & $\stackrel{\Xi}{\stackrel{\Xi}{\Xi}}$ & $\stackrel{\infty}{\stackrel{\infty}{\Xi}}$ & $\Xi$ & $\stackrel{\mathcal{Z}}{\mathrm{Z}}$ & $\stackrel{g}{ \pm}$ & $\underset{\Xi}{\Xi}$ & 导 & $\stackrel{\circ}{J}$ & 导 & $\stackrel{\infty}{+}$ & $\stackrel{\vec{J}}{\mathbf{g}}$ & $\stackrel{8}{9}$ & $\stackrel{\bar{n}}{ \pm}$ & $\stackrel{\tilde{N}}{\mathcal{I}}$ \\
\hline Berg/Horka (7-8) & & & & & & & & 1 & & & & & & & & & & \\
\hline Bruck/Mostek (2-6) & & & & & & & & & & & 1 & & & & & & & \\
\hline Dietersgrün $(9-10)$ & & & & & & & 2 & & & & 1 & & & & & & & \\
\hline Doberau/Doubrava (4-5) & & & & & & & $1^{*}$ & & & & & & & & & & & \\
\hline Dürrnbach/Potočiště (12-13) & & & & & & & 1 & 2 & & & & & 1 & & & & & \\
\hline Ensenbruck/Povodí (5-6) & & 1 & & & & & 1 & & 1 & & & & & & & & & \\
\hline Fischern (10-12) & & & & & & & & 1 & & & & & & & & & & \\
\hline Fonsau/Vonšov (3-5) & & & & & & & & 1 & & & & & & & & & & \\
\hline Frauenreuth/Kopanina (23-28) & $2 *$ & 1 & & & & & & & & & & & & & & & & \\
\hline Gaßnitz/Jesenice (19-23) & $1^{*}$ & & & & & & $1^{*}$ & $1^{*}$ & & & & & 1 & & & & & \\
\hline Gehaag/Háje (11-15) & 1 & & & & & & & & & & & & & & & & & \\
\hline Hart/Lesina (3-5) & 1 & & & & & & 1 & 1 & & & & & & & & & & \\
\hline Hartessenreuth/Hartoušov (5-6) & $1^{*}$ & & & & & & & & & & & & & & & & & \\
\hline Haslau/Hazlov (37-41) & & & & & & 2 & & & & & & & & & & & & \\
\hline Hirschfeld/Polná (9) & & & & & & & & 1 & & & & & & & & & & \\
\hline Höflas/Dvoreček (1-2) & & & & & & & & 1 & & & & & & & & & & \\
\hline Höflas/Dvorek (6-7) & & & & & 1 & & & & & & & & & & & & & \\
\hline Konradsgrün/Salajna (23-25) & 1 & 3 & & & & & & & & & & 1 & 1 & & 1 & 1 & & \\
\hline Kornau/Obilná (4-7) & 1 & & & & & 2 & & & & & & & & & & & & \\
\hline Kunreuth, Ober-/Hraničná Horní (12-13) & & & & & & & & 1 & & & & & & & & & & \\
\hline Liebeneck/Tůně (4) & & & & & & & & 1 & & & & & & & & & & \\
\hline Lindau, Ober-/Lipina Horní (6-8) & & & 1 & & & & & & & & & & & & & & & \\
\hline Lindau, Unter-/Lipina Dolní (6-9) & & & & & & & & & & & & & & & & & 3 & 3 \\
\hline Lohma, Ober-/Lomany Horní (16-25) & & 2 & & & & & 1 & 2 & & & & & & 1 & 1 & 1 & 1 & 1 \\
\hline Lohma, Unter-/Lomany Dolní (6-11) & & & & & & & & & 1 & 1 & 1 & 2 & & & & & & \\
\hline Losau, Unter-/Lažany Dolní (6-11) & 1 & & & & & & & 2 & & 2 & 4 & & & & & & & \\
\hline Markhausen/Pomezná (12-16) & 1 & & & & & & & & & & & & & & & & & \\
\hline Mühlbach/Pomezí nad Ohří (13-16) & & & & 1 & & & 1 & 1 & & & & & & & & & & \\
\hline Mühlessen/Milhostov (13-16) & & & & & & & 1 & 1 & & & & & & & & & & 1 \\
\hline Oberndorf/Horní Ves (10-11) & 1 & & & & & & & 2 & & & & & & & & & & \\
\hline Oed/Poustka (14-17) & 1 & & & & & & & $2^{*}$ & $4^{*}$ & $1^{*}$ & $1^{*}$ & $1^{*}$ & & & & & & \\
\hline Ottengrün u Starého Hrozňatova (12-13) & & & & & & & & & & & & & & & & & & 1 \\
\hline Ottengrün/Otov u Hazlova (6-7) & 1 & & & & & & & 2 & & & & & & & & & & \\
\hline Palitz/Palič (17-18) & & & & & 1 & 2 & & & & & & & & & & & 2 & \\
\hline Pilmersreuth, Ober-/Pelhřimov Horní $(7-10)$ & & & & & & & $1^{*}$ & & & & & & & & & & & \\
\hline Pilmersreuth, Unter-/Pelhřimov Dolní (8-12) & & & & & & & & 1 & & & & & 1 & & & & & \\
\hline Rathsam (9-12) & & & 2 & & & & & 2 & & & 1 & & & & $1^{*}$ & & & \\
\hline Rohr/Nový Drahov (12-14) & & & & & & & & 1 & 1 & 1 & 1 & 1 & & 1 & & & & \\
\hline Rommersreuth/Skalka (13-15) & & & & & 1 & & & 1 & & 1 & 2 & & & & & & & \\
\hline Rossenreuth/Mýtinka (5) & & & & & & & & $1^{*}$ & & & & & & & & & & \\
\hline Sebenbach/Chvoječná (5-6) & $1 *$ & & & & & & & & & & & 1 & & & & & & \\
\hline Seußen $(5-11)$ & & & & & & & & & & 1 & & & & & & & & \\
\hline Scheibenreuth/Okrouhlá (16-18) & 1 & & & & & & 1 & 1 & 3 & & & & 2 & 1 & & & & \\
\hline Schlada/Slatina (11-13) & & & & & & 1 & & & & & 1 & & & & & & & \\
\hline Schöba/Všeboř (14-18) & & & & & 1 & & & & & & & & & & & & & \\
\hline Schön, Unter-/Dvory Dolní (5-7) & $1^{*}$ & & & & & & & & & & & & & & & & & \\
\hline Schüttüber, Groß-/Šitboř Velká (3-9) & 2 & & & & & & & & & & & & & & & & 1 & \\
\hline Sirmitz/Žírovice (7-8) & & & & & & & & 1 & & & 1 & & & & & & & \\
\hline Stabnitz/Stebnice (13-17) & & & & & & & & & & & & 1 & & & & & 1 & 1 \\
\hline
\end{tabular}




\begin{tabular}{|c|c|c|c|c|c|c|c|c|c|c|c|c|c|c|c|c|c|c|}
\hline Název vsi a počet poplatníků & $\underset{\Xi}{\Xi}$ & ฐి & $\stackrel{\widetilde{\Xi}}{\Xi}$ & $\stackrel{\mathscr{\Xi}}{\Xi}$ & $\stackrel{\Xi}{ \pm}$ & $\stackrel{\infty}{\stackrel{\Xi}{\Xi}}$ & $\exists$ & $\stackrel{\mathcal{Z}}{ \pm}$ & $\underset{z}{Z}$ & $\underset{\Xi}{ \pm}$ & $\underset{J}{ \pm}$ & $\stackrel{\circ}{ \pm}$ & 导 & 文 & $\stackrel{\text { J }}{\mathbf{I}}$ & 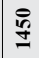 & $\stackrel{\bar{n}}{ \pm}$ & 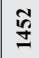 \\
\hline Tipessenreuth/Trpěš (4-5) & & & & & & & & 1 & 1 & 1 & 1 & & & & & & & \\
\hline Treunitz/Dřenice (17-21) & & & & & & & & 1 & & & & & & & & & & \\
\hline Triesenhof/Střižov (6-8) & 1 & & & & & & & & & & & & & & & & & \\
\hline Trogau/Drahov (5-6) & $1^{*}$ & & & & & & & & & & & & & & & & & \\
\hline Ulrichsgrün/Oldřichov (12-14) & & & & & & & & $2 *$ & $2 *$ & & & & & & & & & \\
\hline Voitersreuth, Hinter-/Vojtanov (7-9) & $1^{*}$ & & & & & & & & & 1 & & & & & & & 1 & \\
\hline Voitersreuth, Vorder-/Vojtanov (8-10) & & & & & & & & & & & & 1 & & & & & & \\
\hline Watzgenreuth/Vackovec (5-6) & & & & & & & & & & 1 & & & & & & & & \\
\hline
\end{tabular}

Př́iloha 4. Pusté usedlosti na Chebsku podle berních rejstř́íků z let 1424-1452. V závorce uveden celkový počet poplatníků (zpravidla usedlostí).

Anhang 4. Laut den Steuerbüchern der Jahre 1424-1452 wüste Anwesen. In Klammern Gesamtanzahl der Abgabepflichtigen (in der Regel Anwesen).

\section{Archivní prameny}

Rejstř́ky chebské zemské berně z roku 1392 a 1395:

SObA Plzeň - SOkA Cheb, fond 1, kniha č. 1009, Klosteuerbuch 1392.

SObA Plzeň - SOkA Cheb, fond 1, kniha č. 1054, Klosteuerbuch 1395.

Rejstř́iky chebské zemské berně z let 1397-1409 (čistopisy):

SObA Plzeň - SOkA Cheb, fond 1, knihy č. 1055, Klosteuerbuch 1397 (opis z roku 1769).

SObA Plzeň - SOkA Cheb, fond 1, knihy č. 1055-1059, Klosteuerbuch 1401, 1404, 1408, 1409.

Rejstříky chebské zemské berně z let 1397-1409:

SObA Plzeň - SOkA Cheb, fond 1, kniha č. 3255, Register 15. Jahrh. (berní rejstř́ik pro roky 1397 a 1399).

SObA Plzeň - SOkA Cheb, fond 1, kniha č. 3264, Register 15. Jahrh. (berní rejstř́ik pro rok krátce po 1409).

Rejstř́ky chebské zemské berně z let 1424-1438 (čistopisy):

SObA Plzeň - SOkA Cheb, fond 1, kniha č. 1060, Klosteuerbuch 1424.

SObA Plzeň - SOkA Cheb, fond 1, kniha č. 1062, Klosteuerbuch 1431 (správně 1429, torzo).

SObA Plzeň - SOkA Cheb, fond 1, kniha č. 1066, Klosteuerbuch 1434-1438 (přesněji 1435, př́iliš malé torzo).

SObA Plzeň - SOkA Cheb, fond 1, kniha č. 1067, Klosteuerbuch 1438 (opis z roku 1769; edice Klír T. a kol. 2016).

Rejstř́íky chebské zemské berně z let 1424-1438:

SObA Plzeň - SOkA Cheb, fond 1, kniha č. 1061, Klosteuerbuch 1429.

SObA Plzeň - SOkA Cheb, fond 1, knihy č. 1063-1065, Klosteuerbuch 1432, 1433 a 1434 (kniha z roku 1434 je z velké části ohryzána).

Rejstříky chebské zemské berně z let 1441-1478:

SObA Plzeň - SOkA Cheb, fond 1, knihy č. 1068-1083, 1085-1105, Klosteuerbuch 1441-1478.

Oceňovací berní kniha:

SObA Plzeň - SOkA Cheb, fond 1, kniha č. 1084, Klosteuerbuch (Schätzungsbuch) 1456 (edice Klír, T. a kol. 2016). 


\section{Literatura}

ALFONSO, I., 2007: Comparing National Historiographies of the Medieval Countryside: An Introduction. In: The rural history of medieval European societies: trends and perspectives. The medieval countryside 1 (Alfonso, I., ed.), 1-20. Turnhout.

BARTH, H., 1949: Die Wüstungen der Landkreise Greiz und Schleiz. Beiträge zur mittelalterlichen, neueren und allgemeinen Geschichte 24. Jena.

BARTL, W., 2003: Der böhmische Kriegszug durch Ostoberfranken im Jahre 1462, Archiv für Geschichte von Oberfranken 83, 91-96.

BAUERNFEIND, W., 1993: Materielle Grundstrukturen im Spätmittelalter und der Frühen Neuzeit. Preisentwicklung und Agrarkonjunktur am Nürnberger Getreidemarkt von 1399 bis 1670. Nürnberger Werkstücke zur Stadt- und Landesgeschichte 50. Neustadt a. d. Aisch.

BECKER, H.-ERICSSON, I., edd., 2004: Mittelalterliche Wüstungen im Steigerwald. Bericht über ein Kolloquium des Zentrums für Mittelalterstudien der Universität Bamberg in Verbindung mit dem Lehrstuhl I für Geographie und dem Lehrstuhl für Archäologie des Mittelalters und der Neuzeit. Bamberger geographische Schriften. Sonderfolge 7. Bamberg.

BOHÁC̆, Z., 1983: Vesnice v sídelní struktuře předhusitských Čech - Das Dorf in der Siedlungsstruktur des vorhussitischen Böhmens, Historická geografie 21, 37-116.

- 1986: K problematice a terminologii pustnutí a zanikání sídel v písemných pramenech vrcholného a pozdního středověku - Zur Problematik und Terminologie der Wüstung und des Untergangs von Siedlungen in den schriftlichen Quellen des Hoch- und Spätmittelalters, Historická geografie 25, 269-283.

BORN, M., 1968: Wüstungen und Sozialbrache, Erdkunde 22, 143-151. DOI: https://doi.org/10.3112/ erdkunde.1968.02.04

- 1979: Objektbestimmungen und Periodisierung als Problem der Wüstungsforschung, dargelegt unter vornehmlichem Bezug auf neuere Untersuchungen, Geographische Zeitschrift 67, 43-60.

CERMAN, M., 2008: Social structure and land markets in late medieval central and east-central Europe, Continuity and Change 23, 55-100. DOI: https://doi.org/10.1017/S0268416008006656

ČECHURA, J., 1986: Nejstarší český urbář: Urbář kláštera ve Vyšším Brodě z konce sedmdesátých let 13. století - Das älteste böhmische Urbar. Das Urbar des Klosters in Hohenfurt am Ende der achtziger Jahre des 13. Jahrhunderts, PHS 27, 5-26.

- 1987: Demografický faktor teorie pozdně středověké agrární krize a některé aspekty populačního vývoje v Čechách do konce 15. století - Demographic Factor of the Theory of the Late-Medieval Agrarian Crisis and Some Aspects of the Population Development in Bohemia up to the End of the 15th Century, Historická demografie 12, 89-105.

- 1990: Rolnictvo v Čechách v pozdním středověku. Perspektivy dalšího studia - Die Bauern in Böhmen im Spätmittelalter. Perspektiven für das weitere Studium, ČČH 88, 465-498.

- 1994: Mor, krize a husitská revoluce - Die Pest, die Krise und die hussitische Revolution, ČČH 92 , 286-303.

- 1997: Urbář kláštera Strahov z roku 1410. In: Bibliotheca Strahoviensis. Královská kanonie premonstrátů na Strahově 1 (1995), 25-44. Praha.

DURDÍK, J., 1966: Vojenská hotovost chebského venkova v roce 1395, Historie a vojenství 1966, 561-583.

DYER, Ch., 2010: Villages in crisis: social dislocation and desertion, 1370-1520. In: Deserted Villages Revisited. Explorations in Local and Regional History 3 (Dyer, Ch.-Jones, R., edd.), 28-45. Hatfield.

DYER, Ch.-JONES, R., edd., 2010: Deserted Villages Revisited. Explorations in Local and Regional History 3. Hatfield.

EICHLER, E.-HELLFRITZSCH, V.-RICHTER, J., 1983-1985: Die Ortsnamen des sächsischen Vogtlandes. Herkunft - Entwicklung - Bedeutung, Bd. 1 (Namenbuch); Bd. 2 (Zur Namenkunde und Siedlungsgeschichte). Vogtlandmuseum Plauen, Schriftenreihe, H. 50, 53. Plauen.

ETTEL, E., 2004: Beiträge zur Siedlungsgeschichte des Egerer Kreises unter besonderer Berücksichtigung der Orts- und Flurformen. Quellen und Erörterungen 4. Pressath.

FELGENHAUER-SCHMIEDT, S.-CSENDES, P.-EIBNER, A., edd., 2009: Lebenswelten im ländlichen Raum. Siedlung, Infrastruktur und Wirtschaft. Beiträge zur Mittelalterarchäologie in Österreich 25. Wien.

FISCHER, G., 1941: Die Flurnamen des Gerichtsbezirkes Eger. Sudetendeutsches Flurnamen-Buch 4. Reichenberg.

FISCHER, R., 1940: Zur Namenkunde des Egerlandes. Die slawischen Ortsnamen des Egerlandes und ihre Auswertung für die Lautlehre und Siedlungsgeschichte. Forschungen zur sudetendeutschen Heimatkunde, Allgemeine Reihe 9. Reichenberg - Leipzig. 
- 1955: Namen der Regio Egrana vel Hebana, Beiträge zur Geschichte der deutschen Sprache und Literatur 76, 180-198.

FOKT, K., 2012: Późnośredniowieczne osadnictwo wiejskie na Dolnym Śląsku w świetle badań archeologicznych. Kraków.

FREUND, B., 2003: Sozialbrache - zur Wirkungsgeschichte eines Begriffs - Social Fallow - Aspects of the Effective History of a Term, Erdkunde 47, 12-24.

GRADL, H., 1881: Eger und Heinrich von Plauen (1451-1454), Mittheilungen des Vereines für Geschichte der Deutschen in Böhmen 19, 198-214.

- 1893: Geschichte des Egerlandes (bis 1437). Prag.

GRAUS, F., 1957: Dějiny venkovského lidu v Čechách v době předhusitské II. Od poloviny 13. stol. do roku 1419. Studie a prameny 13. Praha.

HABERLAH-POHL, A., 2011: Münchberg. Der Altlandkreis. Historischer Atlas von Bayern, Franken, Reihe I, 39. München.

HASIL, J., 2016: Chebsko v raném středověku: archeologie středoevropského regionu v 7.-12. století. Praha.

HEISINGER, W., 1938: Die Egerer Klosteuerbücher als Quellen für die Bevölkerungs- und Wirtschaftsgeschichte des Egerlandes im späten Mittelalter. Rkp. dizertační práce, Deutsche Universität, Prag.

HEJNA, A., 1967: Archeologický výzkum a počátky sídlištního vývoje Chebu a Chebska, PA LVIII, 169-271.

- 1971: Archeologický výzkum a počátky sídlištního vývoje Chebu a Chebska II, PA LXII, 488-550.

HÖLLERICH, R., 1977: Rehau-Selb. Ehemaliger Landkreis Rehau und ehemals kreisfreie Stadt Selb. Historisches Ortsnamenbuch von Bayern, Oberfranken 3. München.

KÄUBLER, R., 1935: Die ländlichen Siedelungen des Egerlandes. Leipzig.

KENZLER, H., 2012: Die hoch- und spätmittelalterliche Besiedlung des Erzgebirges: Strategien zur Kolonisation eines landwirtchaftlichen Ungunstraumes. Bamberger Schriften zur Archäologie des Mittelalters und der Neuzeit 4. Bonn.

KLÁPŠTĚ, J., 2016: Hospodaření s vodou ve středověké vsi Ve spáleném u Vyžlovky na Černokostelecku Water management in the medieval village Ve spáleném near Vyžlovka in the Kostelec-nad-Černými-lesy region, AR LXVIII, 119-134.

KLÍR, T., 2008: Osídlení zemědělsky marginálních půd v mladším středověku a raném novověku - Besiedlung und landwirtschaftliche Nutzung marginaler Böden im späten Mittelalter und der frühen Neuzeit. Dissertationes Archaeologicae Brunenses / Pragensesque 5. Praha.

- 2010: Osídlení horských oblastí Čech ve středověku a raném novověku - východiska interdisciplinárního výzkumu - Die Besiedelung der Gebirgsgegenden Böhmens im Mittelalter und der frühen Neuzeit Ausgangspunkte für eine interdisziplinäre Forschung, AH 35, 373-391.

- 2015: Hydronymie Chebska v kontextu severovýchodního Bavorska. K otázce jazykových poměrů v raném středověku - The Hydronymy of the Cheb District in the Context of Northeast Bavaria: On the question of the language situation in the Early Middle Ages, Praehistorica XXXII, č. 2, 173-223.

- 2016: Sociální kontext slovansko-německého jazykového kontaktu. Severovýchodní Bavorsko a Chebsko v raném středověku - Der soziale Kontext des slawisch-deutschen Sprachkontakts : Nordostbayern und das Egerland im Frühmittelalter, AH 41, 301-337.

KLÍR, T. a kol., 2016: Knihy chebské zemské berně z let 1438 a 1456 - Die Egerer Landsteuerbücher von 1438 und 1456. Libri Civitatis X. Praha - Ústí nad Labem.

KLÍR, T.-KENZLER, H., 2009: Srovnávací studium areálů zaniklých středověkých vesnic na základě analýz fosforečnanů. Zaniklá stř̌edověká vesnice Schwarzenbach u Chebu - Vergleichende Untersuchungen von Arealen mittelalterlicher Ortswüstungen anhand von Phosphatanalysen. Die mittelalterliche Ortwüstung Schwarzenbach bei Cheb (Eger), AH 34, 657-680.

KNOLL, V.-KAREL, T., 2012: Burgen im Land zwischen Böhmen und dem Reich. Der gegenwärtige Erkenntnisstand zum älteren Horizont der Adelssitze im Egerland. In: Adel, Burg und Herrschaft an der „Grenze“. Österreich und Böhmen. Studien zur Kulturgeschichte von Oberösterreich 34 (Weigl, H.Birngruber, K.-Schmid, Ch., edd.), 205-220. Linz.

KUBU゚, F., 1997: Štaufská ministerialita na Chebsku. Cheb.

- 2006: Chebský městský stát: počátky a vrcholné období do počátku 16. století. Cheb.

LACKNER, I., 2011: Herzog Ludwig IX. der Reiche von Bayern Landshut (1450)-1479. Reichsfürstliche Politik gegenüber Kaiser und Reichsständen. In: Regensburger Beiträge zur Regionalgeschichte 11, 191-235. Regensburg.

LE I: Libri erectionum archidioecesis Pragensis saeculo XIV. et XV. I (Borový, C., ed.). Pragae 1873.

LEINGÄRTNER, G., 1956: Die Wüstungsbewegungen im Landgericht Amberg vom ausgehenden Mittelalter bis zur Neuorganisation des Landgerichts im Jahre 1803. Münchener Historische Studien, Abt. Bayerische Geschichte 3. München. 
LORENZ, S.-RÜCKERT, P., edd., 2009: Landnutzung und Landschaftsentwicklung im deutschen Südwesten. Zur Umweltgeschichte im späten Mittelalter und in der frühen Neuzeit. Veröffentlichungen der Komission für Geschichtliche Landeskunde in Baden-Württemberg, Reihe B, 173. Stuttgart.

MAUR, E., 1989: Př́ispěvek k demografické problematice předhusitských Čech (1346-1419) - Ein Beitrag zur demographischen Problematik Böhmens in vorhussitischer Zeit (1346-1419), Acta Universitatis Carolinae - Phil. et Hist., Studia historica 34, 7-71.

MÍKA, A., 1960: Poddaný lid v Čechách v první polovině 16. století - Die untertänige Bevölkerung in Böhmen in der ersten Hälfte des 16. Jahrhunderts. Studie a prameny 19. Praha.

MÜLLER, W., 1951: Mittelalterliche Wüstungen in Oberfranken, Archiv für die Geschichte von Oberfranken 35 , č. 3, 40-68.

NEKUDA, V., 1994: Ursachen und Folgen der mittelalterlichen Wüstungen dargestellt am Beispiel Mährens. In: Siedlungsforschung 1994 (Fehn, K. et al., edd.), 103-111. Bonn.

NOCUŃ, P.-FOKT, K.-PRZYBYŁA-DUMIN, A., edd., 2016: Wieś zaginiona. Stan i perspektywy badań. Monografie i materiały MGPE 5. Chorzów.

NODL, M., 1994: Západočeské Stříbro v roce 1380. (Kvantitativní analýza vlivu moru na demografický vývoj středověkého města), Minulostí Západočeského kraje 29 (1993), 7-14.

- 2000: Populační vývoj Stř́ibra v letech 1380-1419. (Integrace - fenomén dějin středověkého města). Věnováno Františku Hoffmannovi k 80. narozeninám - Die Entwicklung der Population von Stř́ibro (Meis) in den Jahren 1380-1419. (Integration - ein Phänomen in der Geschichte einer mittelalterlichen Stadt), Minulostí Západočeského kraje 35, 7-47.

NOHOVÁ, I., 2008: Př́ibuzenské vztahy členů Zelenohorské jednoty. Rkp. rigorózní práce, Pedagogická fakulta Univerzity Karlovy v Praze.

NOVÝ, R., 1965: Studie o předhusitských urbářích, Sborník historický 13, 5-64.

- 1975: Finanční písemnosti předhusitského velkostatku v Čechách - Finanz-Schriftgut der vorhussitischen Grossgrundherrschaft in Böhmen. In: Acta universitatis Carolinae - Philosophice et historica $1-\mathrm{Z}$ pomocných věd historických 3, 47-88. Praha.

ROGLER, J. R., 1960: Die Orts- und Flurnamen des Ascher Bezirkes. München.

ROŽMBERSKÝ, P.-VAŘEKA, P., 2013: Středověké osídlení Rokycanska. Vlastivědná knihovnička SPS 20. Praha.

RUPPERT, K., 1958: Zur Definition des Begriffes „Sozialbrache“, Erdkunde 12, 226-231. DOI: https://doi. org/10.3112/erdkunde.1958.03.06

- 1958a: Sozialbrache in Süd- und Westdeutschland, Berichte zur deutschen Landeskunde 21, 119-125.

SCHOFIELD, P. R., 2003: Peasant and Community in Medieval England 1200-1500. Medieval Culture and Society Series. New York.

SCHOLKMANN, B. et al., edd., 2009: Zwischen Tradition und Wandel: Archäologie des 15. und 16. Jahrhunderts. Tübinger Forschungen zur historischen Archäologie 3. Büchenbach.

SCHREG, R., 2014: Ecological Approaches in Medieval Rural Archaeology, European Journal of Archaeology 17, 83-119. DOI: https://doi.org/10.1179/1461957113Y.0000000045

SIEDLUNGSFORSCHUNG, 1994: Siedlungsforschung. Archäologie - Geschichte - Geographie, Band 12. Schwerpunktthema: Wüstungsprozesse - Wüstungsperioden - Wüstungsräume (Fehn, K. et al., edd.). Bonn.

SIEGL, K., 1904: Zur Geschichte der Fürstentage Georgs von Podiebrad in Eger in den Jahren 1459, 1461 und 1467, Mitteilungen des Vereines für Geschichte der Deutschen in Böhmen 42, 203-226.

SINGER, F. W., ed., 1996: Das Nothaftische Lehensbuch von 1360. Besitz und Verwaltung der Reichsministerialen Nothaft im Historischen Egerland. Faksimile und Übertragung des Orginals im Bayerischen Hauptstaatsarchiv München. Arzberg - Hohenberg.

STADELMANN, 1862: Der abgeschlagene Sturm der Böhmen auf die Stadt Wunsiedel im Jahre 1462, Archiv für Geschichte von Oberfranken 8/3, 33-40.

STEPHAN, H.-G., ed., 2010: Der Solling im Mittelalter: Archäologie - Landschaft - Geschichte im Weserund Leinebergland; Siedlungs- und Kulturlandschaftsentwicklung; die Grafen von Dassel und Nienover. Hallesche Beiträge zur Archäologie des Mittelalters und der Neuzeit 1. Dormagen.

STURM, H., 1952: Eger. Geschichte einer Reichsstadt. Bilderband. Augsburg.

- 1960: Eger. Geschichte einer Reichsstadt. Augsburg. 2. Auflage (1. Auflage 1951).

- 1970: Tirschenreuth. Historischer Atlas von Bayern, Altbayern, Reihe I, 21. München.

- 1981: Districtus Egranus. Eine ursprünglich bayerische Region. Historischer Atlas von Bayern, Altbayern, Reihe II, 1. München.

ÚLOVEC, J., 1998: Hrady, zámky a tvrze na Chebsku. Cheb.

VELIČKA, T., 2014: Lantkrabata z Leuchtenberka v politice lucemburských králů a jejich lenní knihy s ohledem na majetky na Chebsku a Loketsku, Sborník muzea Karlovarského kraje 22, 169-196. 
VÖLKL, G., ed., 1955: Das älteste Leuchtenberger Lehenbuch, Verhandlungen des Historischen Vereins für Oberpfalz und Regensburg 96, 277-404.

WEIß, D., 1997: Das Ringen um die Vormacht. In: Handbuch der bayerischen Geschichte 3. Band 1. Teil: Geschichte Frankens bis zum Ausgang des 18. Jahrhunderts (Spindler, M.-Kraus, A., edd.), 425-441. München. 3. Auflage.

WENDLING, W., 1966: Die Begriffe „Sozialbrache“ und „Flurwüstung“ in Etymologie und Literatur, Berichte zur deutschen Landeskunde 35, 264-310.

\section{Internetové zdroje}

Grimm DWB: GRIMM, J.-GRIMM, W., 1971: Das Deutsche Wörterbuch, Bd. I-XVI (1-33), 1854-1971. Digitální vydání: http://dwb.uni-trier.de/de/die-digitale-version/, cit. 6. 4. 2017.

SEYBOTH, R., 2014: Fürstenkrieg, 1458-1463. In: Historisches Lexikon Bayerns. Dostupné z: http://www. historisches-lexikon-bayerns.de/Lexikon/Fürstenkrieg, 1458-1463, cit. 6. 4. 2017.

\section{Zusammenfassung}

\section{Verödungsprozesse, Kriegsschäden und sog. Sozialbrachen. Das Egerland im Spätmittelalter}

Die vorgelegte Studie hatte zum Ziel, unsere Erkenntnisse über 1) den Verödungsprozess von ländlichen Siedlungen in den neunziger Jahren des 14. Jahrhunderts, 2) den Verlauf und die Auswirkung von lokalen Konflikten im 15. Jahrhundert und 3) über Sozialbrachen zu konkretisieren. Für die detaillierte Analyse wurde das Egerland ausgewählt, und zwar im Hinblick auf die einzigartige Quellenerfassung in Form der Egerer Landsteuerbücher (1392-1757; Klosteuerbücher). Diese erlauben es, die sozialökonomische Entwicklung von mehreren hundert Dörfern zunächst lückenhaft, ab dem Jahr 1441 bereits kontinuierlich, und zwar auf Ebene der einzelnen Anwesen buchstäblich Jahr für Jahr zu beobachten (vgl. Klír a kol. 2016).

Die Aussage der Steuerbücher darf selbstverständlich weder überbewertet, noch geradlinig interpretiert werden. Trotz einer gewissen Skepsis wird aber auch so deutlich, dass die ältesten erhaltenen Bücher aus den Jahren 1392-1409 zwei qualitativ und chronologisch unterschiedliche Ebenen und gleichzeitig auch Gruppen von Dorfwüstungen widerspiegeln. Erstens Dörfer, die eine zeitlang praktisch bereits wüst waren mit langfristig überdauernden Sozialbrachen, an deren Besiedelung mindestens ab den achtziger Jahren des 14. Jahrhunderts kein Interesse mehr bestand. Diese Dörfer waren in der Regel definitiv untergegangen (Kap. 4.1). Zweitens Dörfer, die zwar den tiefsten Punkt ihrer Population erreicht hatten, es sich dabei aber lediglich um eine kurzfristige Schwankung handelte, die bald überwunden werden konnte (Kap. 4.2). Die Fülle an im Steuerbuch von 1397 aufgeführten lang- und auch kurzfristigen Dorfwüstungen spiegelt dabei wahrscheinlich die vorhergehende Pestwelle (1395) wider, die auch in den Egerer Steuerbüchern indiziert ist (Losungsbücher; Kap. 4.3).

Die Verödung der Egerer Dörfer im Spätmittelalter wird von uns als Folge des Zerfalls und Untergangs von landwirtschaftlichen Gemeinschaften vor dem Hintergrund einer hohen Sterblichkeitsrate und Entvölkerung wahrgenommen. In Dörfern mit relativ günstigen Siedlungsbedingungen waren die Sozialbrachen schnell überwunden, in den übrigen Dörfern konnte es zu einer ausgedehnten Verödung kommen. Nach dem Aussterben des Kerns einer landwirtschaftlichen Gemeinschaft, deren Mitglieder zu einem ansonsten relativ unattraktiven Ort starke Bindungen hatten, ging der Rest weg und zurück blieben eher Ältere oder Witwen (Plößberg bei Selb). Wir tendieren somit zu den Strömungen, die im Verödungsprozess die primäre Antriebskraft der demographischen Entwicklung zuschreiben und die übrigen Faktoren als sekundär ansehen. Dadurch wird ihre Bedeutung jedoch nicht geschwächt, denn es waren gerade Faktoren wie natürliche Anlage, Absatzmöglichkeiten, innerer Zusammenhalt der landwirtschaftlichen Gemeinschaften, Interessen der Obrigkeit oder benachbarter landwirtschaftlicher 
Gemeinschaften, die in hohem Maße bestimmt haben, ob eine Verödung überwunden und ein Dorf neu besiedelt wird, oder ob die Besiedelung neu strukturiert wird und das Dorf untergeht.

Die in den zwanziger bis sechziger Jahren des 15. Jahrhunderts in den Steuerbüchern erfassten Dörfer wiesen eine ungewöhnliche Vitalität, wirtschaftliche und demographische Reserven und damit auch Regenerierungspotenzial auf (Kap. 5.1). Infolge von Unglücksfällen oder Kriegsereignissen fielen viele Anwesen als auch ganze Dörfer Bränden zum Opfer, die Untertanen kamen um Vieh, Pferde, Ernte und um totes Inventar, trotzdem wurden die Anwesen immer schnell wieder aufgebaut und die Schäden - zumindest aus Sicht der Steuerpotenz - binnen ein zwei Jahren vollständig überwunden. Zu einem Umbruch kam es in den siebziger Jahren des 15. Jahrhunderts, die als Zeit allgemeiner Steuerausfälle charakterisiert werden kann, die noch tiefergehend analisiert werden müssten.

Nicht besiedelte und wüste Anwesen waren ein gängiges, wenn auch kein Massenphänomen, das mit kurzfristigen wirtschaftlichen Schwankungen und demographischen Zyklen in Verbindung gebracht werden kann (Kap. 5.2). In komplett der Hälfte der beurteilten Dörfer belegte wüste Anwesen verzeichneten langfristig nicht überwundene Sozialbrachen, und damit auch die demographischen oder wirtschaftlichen Schwierigkeiten der landwirtschaftlichen Gemeinschaft. Auch die geringe Anzahl an Wüstungen ändert daran nichts, da nur 18 Steuerbücher analysiert wurden, d.h. lediglich 18 Jahre.

Wüste Anwesen stellten ein dynamisches Element dar, das nicht nur eine Korrektion des Grundrissschemas der Dörfer möglich machte, sondern auch eine Adaptation der landwirtschaftlichen Gemeinschaft. Wenn man das festgestellte Vorkommen und die Häufigkeit von wüsten Anwesen auf einen längeren Zeitabschnitt projiziert, wird uns bewusst, wie überaus lebendig einige dörfliche Innenbereiche pulsieren können.

Unser Schriftstücke des Landsteuerwesens analysierende Beitrag betrifft nur eine Region Mitteleuropas im Spätmittelalter. Für Böhmen und Mähren ist ein methodisch ähnlicher Ansatz erst ab der zweiten Hälfte des 17. Jahrhunderts möglich, als die Steuerrolle und die Hufenregister verfasst wurden.

Die vorliegende Studie ist im Rahmen des Förderprograms Progres der Karls-Universität Nr. Q07 „Zentrum für Mittelalterstudien“ entstanden.

Falls nicht anders angegeben, stammen alle Abbildungen vom Verfasser.

PhDr. Tomáš Klír, Ph.D., Ústav pro archeologii Filozofické fakulty Univerzity Karlovy v Praze, Náměstí Jana Palacha 2, 11638 Praha 1, Česká republika,Tomas.Klir@ff.cuni.cz 
